\title{
CHANGES IN MACROELEMENT CONTENT IN NUPHAR LUTEA (L.) SIBITH. \& SM. DURING THE GROWING SEASON
}

\author{
HENRYK TOMASZEWICZ ${ }^{1}$, HANNA CIECIERSKA ${ }^{2}$ \\ ${ }^{1}$ Department of Plant Ecology and Environmental Conservation, \\ Warsaw University \\ Al. Ujazdowskie 4, 00-478 Warszawa, Poland \\ e-mail: g.tomaszewicz@uw.edu.pl \\ 2 Department of Botany and Nature Protection, \\ University of Warmia and Mazury in Olsztyn \\ Plac Łódzki 1, 10-727 Olsztyn-Kortowo, Poland
}

(Received: January 7, 2009. Accepted: February 25, 2009)

\begin{abstract}
This study presents the results of monitoring studies carried out to determine the chemical composition of $\mathrm{Nu}$ phar lutea in two phytocoenoses of Nupharo-Nymphaeetum albae Tomasz. 1977 occurring in two lakes of different trophic types (eutrophic Lake Laśmiady and oligo-humotrophic Lake Pływające Wyspy). The leaves (collected starting in May), rhizomes and roots of Nuphar lutea as well as water and sediment samples were collected from March to November in the above phytocoenoses (for 3 years in Lake Pływające Wyspy and for 4 years in Lake Łaśmiady). The samples were analysed for several parameters including: phosphate, nitrate, total nitrogen, potassium, sodium, calcium, total iron, sulphate and silica dissolved. In addition the manganese, cadmium, zinc and lead contents were determined in the leaves, rhizomes and roots of the plants collected in July (at the height of the growing season). It was found that the differences in the chemical composition of water and sediments between the lakes studied were more pronounced than in the case of leaves, rhizomes and roots of Nuphar lutea.
\end{abstract}

KEY WORDS: Nuphar lutea, Nupharo-Nymphaeetum albae, macroelements, microelements.

\section{INTRODUCTION}

Data regarding the relationship between the chemical composition of plants and their habitats are usually incomplete and should be treated with caution. Different results were obtained by various authors. In many cases, the samples were taken on different dates, whereas others were collected at the height of the growing season. Moreover, the length of the growing season varies in different regions and largely depends on the meteorological conditions. The duration of this period varies among species. Shifts in the timing and length of the growing season have been observed. Depending on the type of water body the length of the growing season may differ by as much as 2 weeks or over within the same region. We noted that in astatic water bodies Phragmites australis can begin and end its growing season two weeks earlier than in lakes. In some cases, the authors did not indicate whether the plants were sampled in representative phytocoenoses in which the species attained its optimum development or taken randomly. The results of chemical analyses of reedswamp and meadow plants are provided among others in: (Oświt and Sapek 1976, 1982; Oświt 1991). However, in the latter case, the substrate and plant samples were collected before the first mowing. It is, therefore, difficult to establish when the samples were taken and to determine the developmental stage of the species. The samples were collected only once, probably at different periods. In order to clear all doubts monitoring studies were conducted to investigate changes in the chemical composition of water and reedswamp plants during the growing season in relation to water and sediment chemistry. In this study we present the results of such investigations conducted on Nuphar lutea. A review of the literature data shows that these monitoring studies have not been carried out to date. Klink's works (Klink 2004, 2005a, b; Klink et al. 2004) contain many interesting results about the chemical composition of Nuphar lutea leaves (macro- and microelements) in relation to site chemistry.

The objectives of the present work were to: 1) evaluate the changes in the macroelement content of leaves, rhizomes and roots of Nuphar lutea recorded at regular intervals during the growing season in the phytocoenoses of Nupharo-Nymphaeetum albae from two lakes with different trophic conditions; 2) determine the changes in properties of water and sediments of the phytocoenoses with Nuphar lutea; 3) establish the relationship between the chemical 
composition of Nuphar lutea and the chemical composition of water and sediments.

\section{MATERIAL AND METHODS}

\section{Study area and chemical analyses}

Two representative phytocoenoses of Nupharo-Nymphaeetum albae $(\mathrm{N}-\mathrm{N})$ were monitored in two lakes (Lakes Łaśmiady and Pływające Wyspy) within the Ełk Lake District (Fig. 1). Nuphar lutea was the species building and dominating the phytocoenoses studied. The cover abundance value for the species according to the Braun-Blanquet (1951) scale was estimated at 5 (with cover intervals $75-100 \%$ ). The two lakes differed greatly in trophic status. Lake Łaśmiady is a typical eutrophic drainage lake (like most of the lakes in this region), whereas Lake Pływające Wyspy is an oligo-humotrophic lake, with no inflow or outflow, surrounded by a peat bog.

Samples of water, sediments and plants (leaves, rhizomes and roots of Nuphar lutea) were taken for chemical analyses in one phytocoenosis of N-N growing in Lake Łaśmiady (1997-2000) and in one phytocoenosis of N-N in Lake Pływające Wyspy (1998-2000). The samples were collected from March to November on the 10th or 11th day of each month. The results for March are regarded as data obtained before the growing season, whereas those for November - at the end of the growing season. Data regarding the chemical composition of leaves were collected starting in May when the first leaves appeared on the water surface. The lack of chemical data for Nuphar lutea leaves from Lake Łaśmiady in November is due to the absence of floating leaves within the phytocoenosis. During the growing season the leaves of Nuphar lutea become more intensively eaten by insects. As a result, the leaves decay and decompose much more quickly.

Water samples were taken from an intermediate depth at which a given phytocoenosis occurred and transferred to two $750 \mathrm{ml}$ plastic containers. Half of the samples were preserved by the addition of $0.75 \mathrm{~cm}^{3} \mathrm{H}_{2} \mathrm{SO}_{4}$ for $\mathrm{PO}_{4}, \mathrm{NO}_{3}$, total $\mathrm{N}$ and total $\mathrm{Fe}$ analyses. The other samples were analysed for $\mathrm{SO}_{4}, \mathrm{SiO}_{2}$ dissolved, $\mathrm{Na}, \mathrm{K}$ and $\mathrm{Ca}$. Prior to the analyses all the samples were filtered and stored in refrigerators at $4^{\circ} \mathrm{C}$ until all the analyses were performed.

The leaves (with petioles) as well as the rhizomes and roots (about $0.75 \mathrm{~kg}$ each) were washed and cleaned thoroughly, and then rinsed with distilled water. Subsequently they were dried and cut into small pieces. About 400-450 $\mathrm{g}$ of leaf and rhizome samples were dried at $65^{\circ} \mathrm{C}$ to constant weight. The dried plant material was subsequently milled to a powder (in a Cyclotec Mill) and then placed in air-tight containers. Water and acid extracts for chemical analysis were prepared from the ground plant material. The water extracts were obtained by addition of $200 \mathrm{ml}$ of distilled water to each $2 \mathrm{~g}$ of leaf and rhizome samples. After 24 hours (the solutions were stirred more than several times during the day) all the solutions were filtered into 500 $\mathrm{ml}$ flasks and the concentrations of $\mathrm{SiO}_{2}$ dissolved and $\mathrm{NO}_{3}$ were determined. In the case of solutions used for determinations of total $\mathrm{Fe}, \mathrm{PO}_{4}, \mathrm{SO}_{4}$ and $\mathrm{Ca}$ each sample containing $0.5 \mathrm{~g}$ of the ground plant material was first digested in $10 \mathrm{ml} \mathrm{HCL}(1+1)$ for $2 \mathrm{~h}$ and then $100 \mathrm{ml}$ of distilled water was added. After 24 hours (the solutions were stirred more than several times during the day) all the

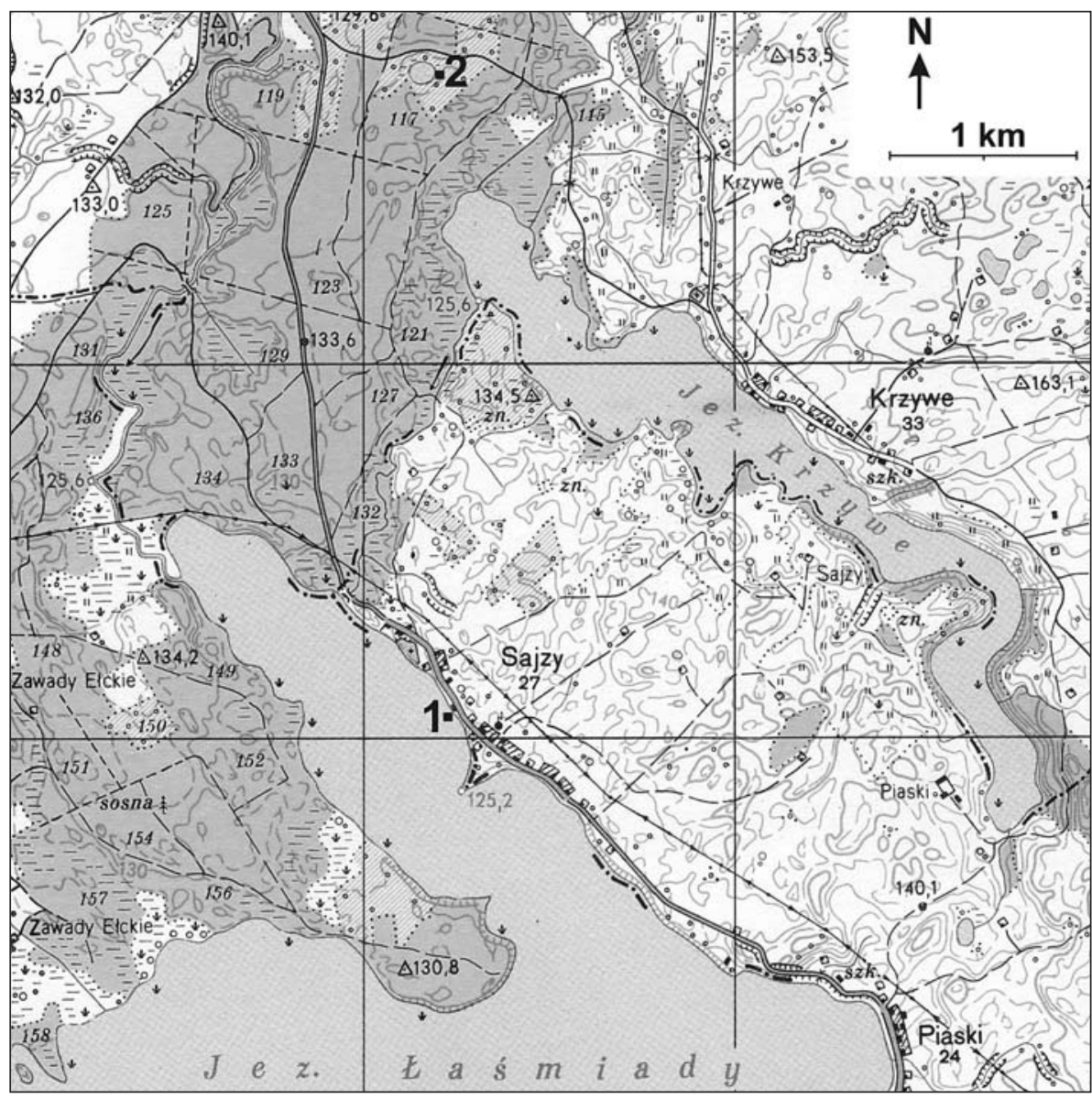

Fig. 1. Location of the study sites: 1 - Lake Łaśmiady, 2 - Lake Pływające Wyspy. 
extracted solutions were filtered into $250 \mathrm{ml}$ flasks. The dry mineral matter and organic content were determined by ignition of $0.5 \mathrm{~g}$ ground plant samples at $550^{\circ} \mathrm{C}$ for $90 \mathrm{mi}-$ nutes. Concentrations of $\mathrm{Na}$ and $\mathrm{K}$ were determined from the ash materials. In order to determine the total nitrogen content, samples containing $0.2 \mathrm{~g}$ of the ground plant material were taken for analysis.

Each sediment sample was a mixture of 3 random subsamples taken within a phytocoenosis from the rhizomeroot layer. The collected samples were stored in air-tight plastic bags at $4^{\circ} \mathrm{C}$. Hydration was determined by drying $100 \mathrm{~g}$ samples at $105^{\circ} \mathrm{C}$ to constant weight. Mineral and organic matter content were determined from $1 \mathrm{~g}$ samples of dry substrate. Determinations of $\mathrm{Na}$ and $\mathrm{K}$ were made from the ash materials. Total nitrogen content was determined from $1 \mathrm{~g}$ samples of dry mineral sediment (Lake Łaśmiady) and $0.3 \mathrm{~g}$ samples of dry organic sediment (Lake Pływające Wyspy). The water extracts were prepared from wet samples containing $2 \mathrm{~g}$ of dry sediment, whereas the acid extracts from wet samples containing $1 \mathrm{~g}$ of dry sediment. Further procedures for obtaining the water and acid extracts were the same as in the case of plants. The same parameters were analysed in the sediment and plant samples.

The samples were analysed for: total $\mathrm{N}$ by Kjeldahl's method, $\mathrm{NO}_{3}$ spectrophotometrically with phenoldisulphonic acid, $\mathrm{PO}_{4}$ spectrophotometrically by molybdate method, total $\mathrm{Fe}$ spectrophotometrically by the rhodonate method, $\mathrm{SO}_{4}$ spectrophotometrically by the nephelometric method, $\mathrm{SiO}_{2}$ dissolved spectrophotometrically by the molybdate method, $\mathrm{Ca}, \mathrm{Na}$ and $\mathrm{K}$ with a flame spectrophotometer.

The methods described in the following works were used to prepare the water and acid extracts and to determine the macroelement concentrations: Hermanowicz et al. (1976), Bayly and Freeman (1977), Kimball and Baker (1982), Gopal and Sharma (1984), Ostrowska et al. (1991).

In the leaf and rhizome samples from July (at the height of the growing season) the following properties were assessed: $\mathrm{Mn}, \mathrm{Cd}, \mathrm{Zn}$ and $\mathrm{Pb}$ by the ASA method.

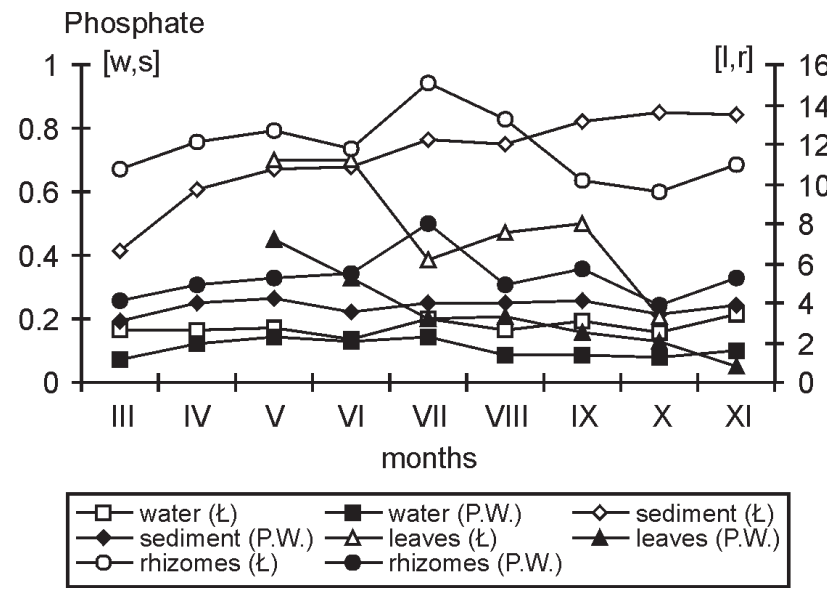

Fig. 2. Variations in $\mathrm{PO}_{4}$ concentrations during the study period: $\mathrm{w}-$ water $\mathrm{mg} / \mathrm{dm}^{3} ; \mathrm{s}$ - sediment $\mathrm{g} / \mathrm{kg}$ dry matter; 1 - leaves $\mathrm{g} / \mathrm{kg}$ dry matter; $\mathrm{r}$ rhizomes and roots $\mathrm{g} / \mathrm{kg}$ dry matter; - Lake Łaśmiady; P.W. - Lake Pływające Wyspy.

\section{Statistical analyses}

The results given in tables and graphs are obtained as the average of results of four years of studies in the phytocoenosis of N-N in Lake Łaśmiady ( $\mathrm{E}$ ) and three years of studies in Lake Pływające Wyspy (P.W.).

STATISTICA package (StatSoft Inc. 2003; Stanisz 1998) was used in this paper for comparison of average values of all the chemical parameters occurring in the leaves, rhizomes and roots of Nuphar lutea and in the environment (water, sediment). This package was used for PCA analysis (Principal Components Analysis), correlation (R) and ANOVA test (Kruskal-Wallis test for nonparametric data). A classification was performed using PCCA (Principal Component Analysis and Classification).

A transformation of original data was neccessary for the purpose of statistical analysis (Jongman et al. 1987; the Shapiro-Wilk test for normality). The Blis transformation was used for PCA analysis $(\ln +1$ - ter Braak and Šmilauer 2002).

\section{RESULTS AND DISCUSSION}

\section{Phosphates}

Phosphorus is one of the primary macroelements required by plants for their growth, which influences primary production. Phosphates usually exist in the inorganic form in the leaves and roots of plants.

During the growing season the $\mathrm{PO}_{4}$ levels in the waters of the phytocoenoses investigated did not change significantly. Higher values of this parameter (in some months even two-fold) occurred in the waters of the N-N phytocoenosis from Lake Łaśmiady (Table 1, Fig. 2). The lowest concentration of $\mathrm{PO}_{4}$ in the waters of both lakes was noted during the intensive flowering of Nuphar lutea (in June).

The $\mathrm{PO}_{4}$ levels in the sediments of the N-N phytocoenoses studied varied during the growing season. In extreme cases, the sediments of N-N phytocoenosis from Lake Laśmiady contained four times as much $\mathrm{PO}_{4}$ as the sediments from Lake Pływające Wyspy. From spring to autumn a gradual increase in $\mathrm{PO}_{4}$ content was noted in the sediments of the phytocoenosis from Lake Łaśmiady. At the end of the growing season the $\mathrm{PO}_{4}$ levels were two times higher than at the beginning of the growing season. In the sediments of the N-N phytocoenosis from Lake Pływające Wyspy the concentration of this nutrient increased slightly from spring to autumn. Minimum changes in $\mathrm{PO}_{4}$ were observed at the height of the growing season.

In substrate solutions phosphorus is present primarily in the form of phosphate ions $\mathrm{HPO}_{4}^{-2}$ and $\mathrm{H}_{2} \mathrm{PO}_{4}^{-}$. The ratio of these two ions depends on $\mathrm{pH}$. At $\mathrm{pH} 5, \mathrm{HPO}_{4}{ }^{-2}$ ions are practically absent, whereas at $\mathrm{pH} 7$, the two kinds of ions are in almost identical proportions.

In the case of sediments from Lake Pływające Wyspy ( $\mathrm{pH} \approx 4$ ), only $\mathrm{H}_{2} \mathrm{PO}_{4}^{-}$ions were probably present, whereas in the sediments of the phytocoenosis from Lake Łaśmiady $(\mathrm{pH} \approx 7.5)$ the $\mathrm{HPO}_{4}{ }^{-2}$ ions occurred more often than the $\mathrm{H}_{2} \mathrm{PO}_{4}^{-}$ions.

Phosphates are very mobile within the plant where they can move up and down the stem. The young roots of the plants are supplied with phosphates taken up by roots or through translocation from the old leaves. 
TABLE 1. Phosphate concentrations in water, sediment, leaves, rhizomes and roots.

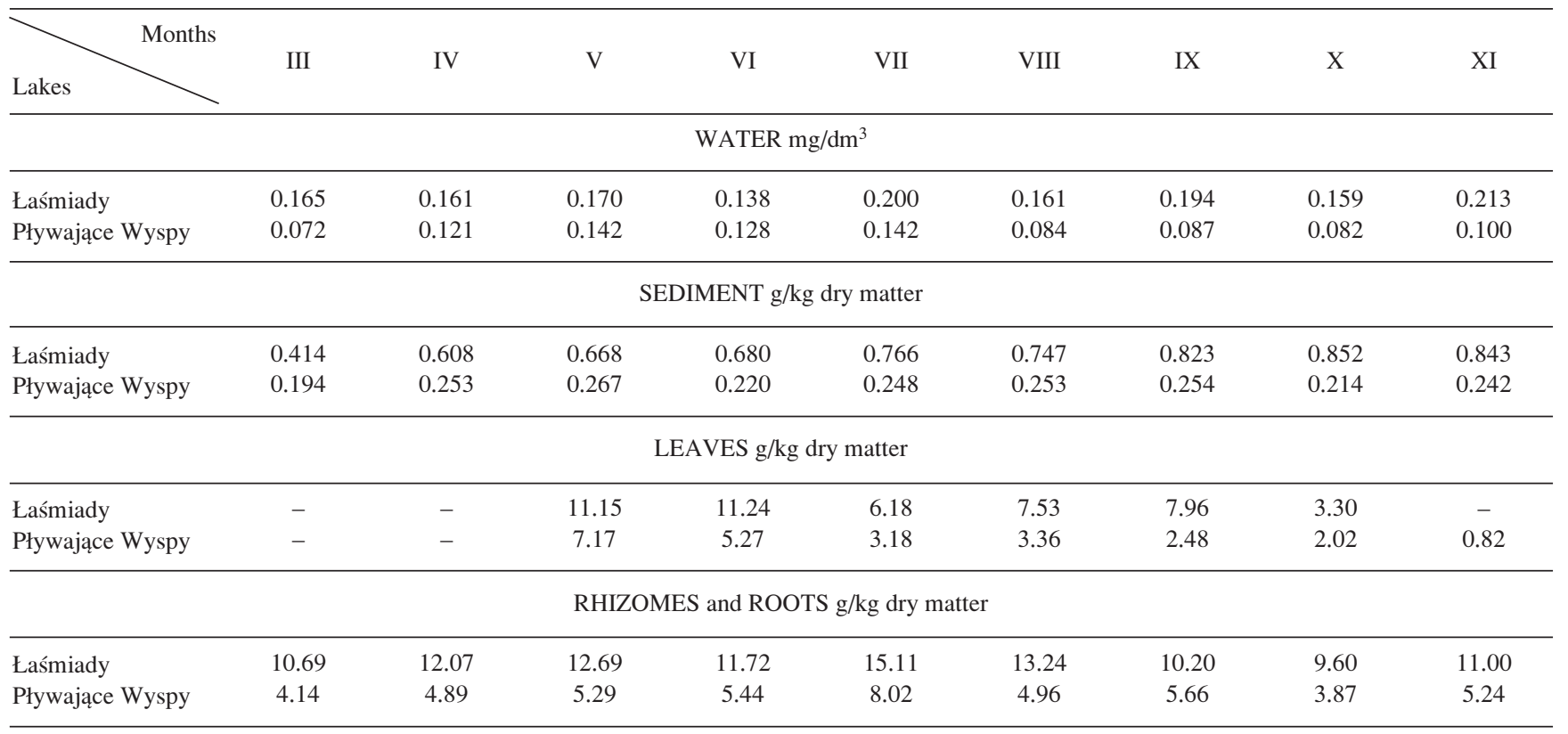

The $\mathrm{PO}_{4}$ content of leaves of Nuphar lutea collected from Lake Pływające Wyspy decreased sharply from May to July. In the following months the decline was far less drastic. In November the $\mathrm{PO}_{4}$ values were more than eight times lower than in May. In the case of leaves of Nuphar lutea from Lake Laśmiady, a somewhat different trend was demonstrated. At the beginning of the growing season the leaves of Nuphar lutea from the latter lake contained over 50\% more $\mathrm{PO}_{4}$ than those from Lake Pływające Wyspy. A sharp decline was observed from June to July (during intensive flowering and fruiting periods). During the next two months there was a slight increase in $\mathrm{PO}_{4}$ content and later a sharp decrease from September to October. At the end of the growing season the $\mathrm{PO}_{4}$ levels in the leaves of Nuphar lutea sampled in Lake Łaśmiady were over three times higher than in the leaves from Lake Pływajace Wyspy.

Considerable differences were found in the $\mathrm{PO}_{4}$ content between the rhizomes and roots of Nuphar lutea collected from Lakes Łaśmiady and Pływające Wyspy. During the entire growing season the $\mathrm{PO}_{4}$ levels in the rhizomes and roots of Nuphar lutea from Lake Laśmiady were two times higher than those in the rhizomes and roots from Lake Pływające Wyspy. The $\mathrm{PO}_{4}$ levels in the rhizomes of Nuphar lutea from the two lakes were subject to similar variations during the growing season. In both cases, the highest values of this parameter were noted in July. At the same time, the lowest $\mathrm{PO}_{4}$ levels occurred in the leaves. Starting July the $\mathrm{PO}_{4}$ content of the rhizomes and roots declined sharply. At the end of the growing season, the $\mathrm{PO}_{4}$ levels were similar to those recorded in April.

It may be assumed that the sharp decline in $\mathrm{PO}_{4}$ of the leaves and rhizomes of Nuphar lutea from Lake Pływające Wyspy (leaves - in May, and rhizomes in June) was associated with the flowering of the plant and fruit production. High $\mathrm{PO}_{4}$ concentrations in the sediments of the N-N phytocoenosis from Lake Laśmiady may slightly influence the level of $\mathrm{PO}_{4}$ in the leaves during the flowering and fruiting periods. It was found that the $\mathrm{PO}_{4}$ concentrations in the rhizomes declined sharply from July to September.
In phosphate-rich habitats the leaves, rhizomes and roots of Nuphar lutea contain twice as much $\mathrm{PO}_{4}$ compared to phosphate-poor areas. The $\mathrm{PO}_{4}$ levels in Nuphar lutea were related to the concentrations of this element in the habitat.

\section{Nitrates}

Plants can take in and metabolize the nitrate and ammonium form of nitrogen. Nitrates are a major source of nitrogen for plants. However, first they must be reduced to $\mathrm{NH}_{3}$ ( $\mathrm{NO}_{3}{ }^{-}$to $\mathrm{NO}_{2}{ }^{-}$and then $\mathrm{NO}_{2}{ }^{-}$to $\mathrm{NH}_{3}$ in the chloroplast).

In April and May the concentration of $\mathrm{NO}_{3}$ in the waters of the N-N phytocoenosis from Lake Laśmiady was two times higher than in the waters of the phytocoenosis from Lake Pływające Wyspy (Table 2, Fig. 3). From June to October, the variations of $\mathrm{NO}_{3}$ concentration in the waters of both phytcoenoses were found to be small. In November the concentration of this element was higher in the waters of Lake Łaśmiady. However its values were three times lower than in March.

Similar $\mathrm{NO}_{3}$ contents were noted in the sediments of the two phytocoenoses studied and the level of this nutrient remained fairly constant during the entire growing season. In November the sediments of both phytocoenoses contained slightly smaller amounts of $\mathrm{NO}_{3}$ than in March.

Although similar $\mathrm{NO}_{3}$ concentrations were found in the water and sediments of both phytocoenoses, the levels of this element varied significantly in the leaves. The leaves of Nuphar lutea sampled in Lake Pływające Wyspy usually contained a higher amount of $\mathrm{NO}_{3}$ than those from Lake Łaśmiady. In the case of the two phytocoenoses studied the $\mathrm{NO}_{3}$ content of the leaves increased at the beginning of the growing season. The highest values of this nutrient were recorded from June to August. Starting August the level of $\mathrm{NO}_{3}$ declined sharply. In both cases the $\mathrm{NO}_{3}$ concentrations were higher at the beginning of the growing season than at its end.

The $\mathrm{NO}_{3}$ content of the rhizomes and roots of Nuphar lutea collected from the two lakes studied increased from March to April and then decreased rapidly in May after the leaves started to develop. In Lake Pływające Wyspy a si- 
TABLE 2. Nitrate concentrations in water, sediment, leaves, rhizomes and roots.

\begin{tabular}{|c|c|c|c|c|c|c|c|c|c|}
\hline Lakes & III & IV & V & VI & VII & VIII & IX & $X$ & XI \\
\hline \multicolumn{10}{|c|}{ WATER mg/dm ${ }^{3}$} \\
\hline Łaśmiady & 0.275 & 0.124 & 0.126 & 0.074 & 0.046 & 0.054 & 0.051 & 0.055 & 0.099 \\
\hline Pływające Wyspy & 0.079 & 0.056 & 0.064 & 0.064 & 0.043 & 0.061 & 0.074 & 0.049 & 0.058 \\
\hline \multicolumn{10}{|c|}{ SEDIMENT g/kg dry matter } \\
\hline Łaśmiady & 0.014 & 0.014 & 0.009 & 0.014 & 0.009 & 0.008 & 0.008 & 0.009 & 0.011 \\
\hline Pływające Wyspy & 0.018 & 0.020 & 0.014 & 0.010 & 0.008 & 0.009 & 0.022 & 0.012 & 0.013 \\
\hline \multicolumn{10}{|c|}{ LEAVES $\mathrm{g} / \mathrm{kg}$ dry matter } \\
\hline Łaśmiady & - & - & 0.183 & 0.272 & 0.318 & 0.282 & 0.210 & 0.148 & - \\
\hline Pływające Wyspy & - & - & 0.299 & 0.372 & 0.279 & 0.339 & 0.300 & 0.232 & 0.199 \\
\hline \multicolumn{10}{|c|}{ RHIZOMES and ROOTS g/kg dry matter } \\
\hline Łaśmiady & 0.335 & 0.412 & 0.133 & 0.128 & 0.186 & 0.159 & 0.166 & 0.198 & 0.169 \\
\hline Pływające Wyspy & 0.275 & 0.341 & 0.135 & 0.211 & 0.365 & 0.268 & 0.129 & 0.183 & 0.198 \\
\hline
\end{tabular}

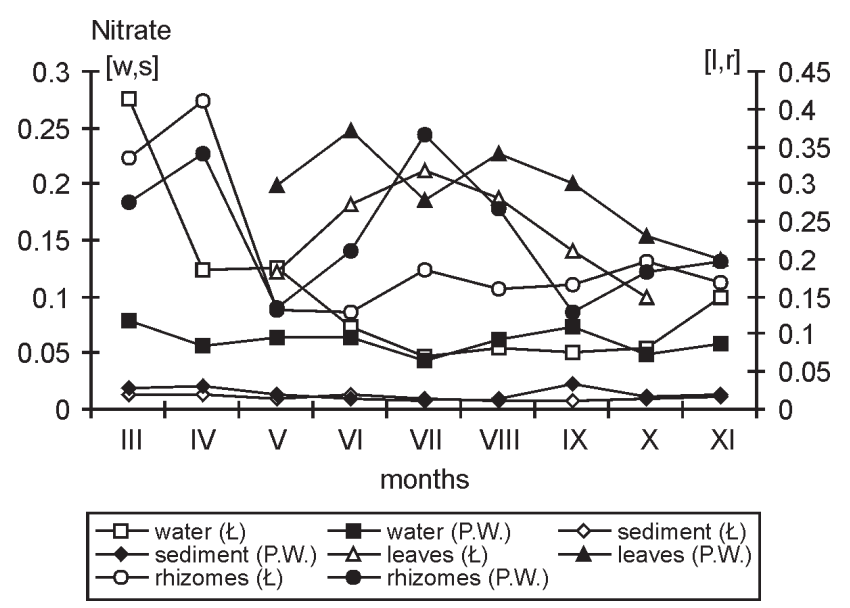

Fig. 3. Variations in $\mathrm{NO}_{3}$ concentrations during the study period: $\mathrm{w}-$ water $\mathrm{mg} / \mathrm{dm}^{3} ; \mathrm{s}$ - sediment $\mathrm{g} / \mathrm{kg}$ dry matter; 1 - leaves $\mathrm{g} / \mathrm{kg}$ dry matter; $\mathrm{r}$ rhizomes and roots $\mathrm{g} / \mathrm{kg}$ dry matter; $€$ - Lake Łaśmiady; P.W. - Lake Pływające Wyspy.

gnificant increase in $\mathrm{NO}_{3}$ levels was noted from May to July (maximum increase in July during the fruiting period). At the same time, the content of this nutrient in the leaves was reduced. From July to September, the $\mathrm{NO}_{3}$ values dropped suddenly and later rose gradually until the end of the growing season. At the end of the growing season the $\mathrm{NO}_{3}$ levels in the rhizomes and roots were much lower than in March. In the case of Lake Laśmiady the $\mathrm{NO}_{3}$ content of the rhizomes and roots showed an increase from March to April and then a rapid decline in May and June (appearance of leaves and flowering period). In July a slight increase in $\mathrm{NO}_{3}$ was observed (in the case of Lake Pływajace Wyspy the $\mathrm{NO}_{3}$ levels exhibited a sharp rise in July). Over the next few months the variations in $\mathrm{NO}_{3}$ levels were found to be small. At the end of the growing season the rhizomes and roots contained more than two times less $\mathrm{NO}_{3}$ than in April and almost two times less $\mathrm{NO}_{3}$ than in March.

Nowotny-Mieczyńska (1965) and Samecka-Cymerman (1995) indicated that plants took up more nitrogen when higher concentrations of phosphorus were found in the habitat. The present results confirm the above finding of a positive correlation between phosphorus and total nitrogen. However, a negative correlation was observed in the case of nitrogen-nitrate $(\mathrm{R}=-0.62)$.

\section{Total nitrogen}

The total nitrogen concentrations (ammonium nitrogen + organic nitrogen) in the waters of Lake Łaśmiady were slightly higher than those in the waters of Lake Pływajace Wyspy. In both lakes, the values of this parameter were higher at the beginning of the growing season than at its end. And also considerable variations in total $\mathrm{N}$ levels were not observed during the study period (Table 3, Fig. 4).

The total $\mathrm{N}$ content in the sediments of Lake Pływające Wyspy was several dozens of times higher than in the sediments of Lake Łaśmiady. In both cases the sediments contained higher amounts of total $\mathrm{N}$ at the beginning of the growing season than in November. The variations in total $\mathrm{N}$ were more pronounced in the sediments of Lake Łaśmiady.

High total $\mathrm{N}$ contents of the sediments in Lake Pływające Wyspy were not positively correlated with total $\mathrm{N}$ content of the leaves. The leaves of Nuphar lutea sampled in Lake Łaśmiady had higher total $\mathrm{N}$ content than those in Lake Pływające Wyspy (except in May). In the latter lake the total $\mathrm{N}$ values decreased gradually from May to November (a slight increase was observed only in September). Larger variations in total $\mathrm{N}$ were noted in Lake Łaśmiady. In both lakes the leaves tended to have higher levels of this nutrient at the beginning and at the height of the growing season than at its end. The greater levels of total $\mathrm{N}$ observed in May and June were associated with the period of most intensive leaf growth. The drop in total $\mathrm{N}$ content at the end of the growing season was attributed to the translocation of nutrients from the leaves to the underground plant parts (Kajak 1979).

During the growing season higher total $\mathrm{N}$ contents were found in the rhizomes of Nuphar lutea collected from Lake Łaśmiady. However, before and at the very beginning of the growing season higher levels of this nutrient were de- 
TABLE 3. Total nitrogen concentrations in water, sediment, leaves, rhizomes and roots

\begin{tabular}{|c|c|c|c|c|c|c|c|c|c|}
\hline Lakes & III & IV & V & VI & VII & VIII & IX & $\mathrm{X}$ & XI \\
\hline \multicolumn{10}{|c|}{ WATER mg/dm ${ }^{3}$} \\
\hline Łaśmiady & 1.34 & 1.38 & 1.09 & 1.00 & 1.02 & 1.29 & 1.01 & 0.85 & 0.86 \\
\hline Pływające Wyspy & 1.06 & 1.20 & 0.80 & 0.97 & 0.94 & 0.44 & 0.67 & 0.60 & 0.91 \\
\hline \multicolumn{10}{|c|}{ SEDIMENT g/kg dry matter } \\
\hline Łaśmiady & 0.77 & 1.85 & 0.34 & 0.37 & 0.53 & 0.40 & 0.54 & 0.72 & 0.39 \\
\hline Pływające Wyspy & 22.22 & 19.64 & 22.67 & 17.94 & 19.34 & 19.51 & 19.31 & 20.94 & 15.46 \\
\hline \multicolumn{10}{|c|}{ LEAVES $\mathrm{g} / \mathrm{kg}$ dry matter } \\
\hline Łaśmiady & - & - & 30.53 & 33.35 & 27.37 & 24.09 & 22.46 & 25.19 & - \\
\hline Pływające Wyspy & - & - & 35.05 & 27.83 & 20.89 & 17.92 & 19.23 & 16.67 & 12.92 \\
\hline \multicolumn{10}{|c|}{ RHIZOMES and ROOTS g/kg dry matter } \\
\hline Łaśmiady & 5.73 & 7.37 & 17.97 & 15.43 & 11.67 & 8.04 & 11.97 & 12.84 & 11.56 \\
\hline Pływające Wyspy & 7.04 & 7.95 & 13.52 & 10.96 & 11.58 & 9.88 & 8.93 & 7.78 & 11.09 \\
\hline
\end{tabular}

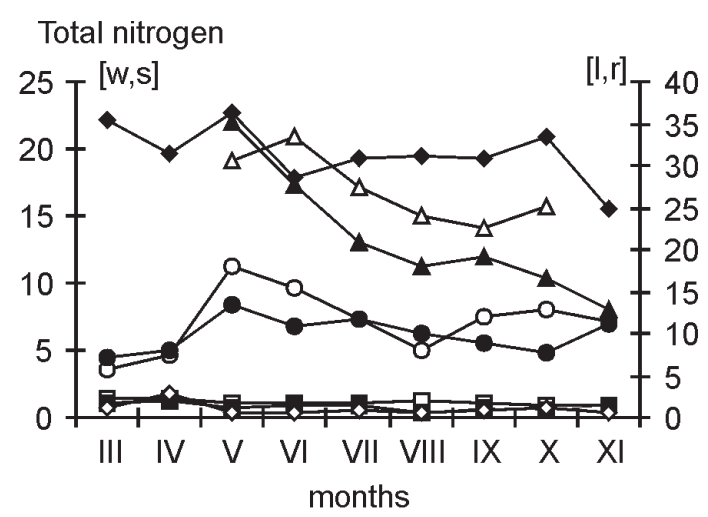

\begin{tabular}{|c|c|}
\hline 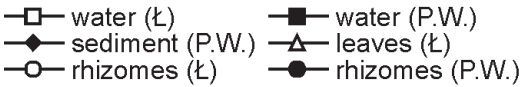 & $\begin{array}{l}\checkmark \text { - sediment }(Ł) \\
\neg \text { leaves (P.W.) }\end{array}$ \\
\hline
\end{tabular}

Fig. 4. Variations in total $\mathrm{N}$ concentrations during the study period: $\mathrm{w}-$ water $\mathrm{mg} / \mathrm{dm}^{3} ; \mathrm{s}$ - sediment $\mathrm{g} / \mathrm{kg}$ dry matter; 1 - leaves $\mathrm{g} / \mathrm{kg}$ dry matter; $\mathrm{r}$ - rhizomes and roots $\mathrm{g} / \mathrm{kg}$ dry matter; $Ł$ - Lake Łaśmiady; P.W. - Lake Pływające Wyspy.

termined in the rhizomes sampled in Lake Pływające Wyspy. In both lakes total $\mathrm{N}$ values were higher at the end of the growing season than in March and April. The rhizomes of Nuphar lutea sampled in both lakes had similar levels of total $\mathrm{N}$ in November.

Greater levels of total $\mathrm{N}$ in the leaves, compared to those in the rhizomes and roots, were associated with the assimilation processes that occur within the above-ground parts of the plant in which nitrogen plays a key role (Czerwiński and Traczyk 1985).

The high total $\mathrm{N}$ concentrations in the sediments of Lake Pływające Wyspy were negatively correlated with the total $\mathrm{N}$ concentrations in the leaves and rhizomes $(\mathrm{R}=-0.34)$. It is unlikely that slightly higher total $\mathrm{N}$ and $\mathrm{NO}_{3}$ concentrations (Tables 2 and 3, Figs 3 and 4) in the waters of Lake Łaśmiady could be responsible for the higher levels of this nutrient in the leaves and rhizomes. Marczonek (1984) did not indicate any relationship between the nitrogen content in plants and in their habitat (water and sediments).

\section{Potassium}

The main source of potassium for plants are sediments. It is taken up in fairly large amounts by plants through active transport. Potassium is a very mobile nutrient within the plant, and is preferentially transported to meristematic tissues. It is often translocated from old (e.g. leaves) to young parts of the plant. Potassium is taken up most intensively by plants during their vegetative growth.

At the height and the end of the growing season, the $\mathrm{K}$ concentrations in the waters of Lake Łaśmiady were two times higher than those in the waters of Lake Pływające Wyspy (Table 4, Fig. 5). In the waters of Lake Łaśmiady the $\mathrm{K}$ values did not change significantly during the growing season. At the end of the growing season the concentrations of this element were higher than in March. The highest $\mathrm{K}$ levels were recorded in April. A reverse trend was demonstrated in the case of waters of the phytocoenosis from Lake Pływające Wyspy. In April the K values were more than two times higher than in November. A sudden drop in $\mathrm{K}$ concentration occurred in the waters of the above phytocoenosis from April to May. The levels of K increased slightly in June and then remained fairly constant until the end of the growing season. Similar variations in the concentration of $\mathrm{K}$ were observed in the waters of the two phytocoenoses studied.

During the entire growing season the sediments of the phytocoenosis from Lake Pływające Wyspy contained greater amounts of $\mathrm{K}$. The differences were most pronounced (two-fold) before and at the end of the growing season.

The leaves of Nuphar lutea sampled in Lake Łaśmiady had higher $\mathrm{K}$ content $(\approx 50 \%)$. During the growing season the levels of this element varied little in both phytocoenoses. The results obtained in this study indicated that the leaf $\mathrm{K}$ content was correlated with $\mathrm{K}$ concentration of water ( $\mathrm{R}=0.61$ in the case of Lake Łaśmiady).

The rhizomes and roots of Nuphar lutea collected in both phytocoenoses contained similar amounts of K. At the height of the growing season (May-August), however, there were higher levels of $\mathrm{K}$ in the rhizomes of Nuphar lutea from Lake Łaśmiady. In both phytocoenoses the highest 
TABLE 4. Potassium concentrations in water, sediment, leaves, rhizomes and roots.

\begin{tabular}{|c|c|c|c|c|c|c|c|c|c|}
\hline Lakes & III & IV & V & VI & VII & VIII & IX & $X$ & XI \\
\hline \multicolumn{10}{|c|}{ WATER mg/dm ${ }^{3}$} \\
\hline Łaśmiady & 2.03 & 3.10 & 2.55 & 2.22 & 2.36 & 2.62 & 2.09 & 2.53 & 2.41 \\
\hline Pływające Wyspy & 2.38 & 2.32 & 0.65 & 1.11 & 0.82 & 1.04 & 0.73 & 0.84 & 0.91 \\
\hline \multicolumn{10}{|c|}{ SEDIMENT g/kg dry matter } \\
\hline Łaśmiady & 0.20 & 0.21 & 0.28 & 0.15 & 0.20 & 0.21 & 0.12 & 0.15 & 0.13 \\
\hline Pływające Wyspy & 0.45 & 0.26 & 0.28 & 0.22 & 0.23 & 0.23 & 0.26 & 0.25 & 0.28 \\
\hline \multicolumn{10}{|c|}{ LEAVES g/kg dry matter } \\
\hline Łaśmiady & - & - & 25.26 & 29.00 & 27.61 & 24.77 & 25.35 & 24.91 & - \\
\hline Pływające Wyspy & - & - & 20.91 & 20.12 & 19.75 & 19.24 & 17.81 & 20.86 & 24.63 \\
\hline \multicolumn{10}{|c|}{ RHIZOMES and ROOTS g/kg dry matter } \\
\hline Łaśmiady & 21.72 & 23.39 & 26.16 & 27.83 & 31.40 & 25.34 & 23.47 & 30.02 & 26.73 \\
\hline Pływające Wyspy & 26.67 & 24.89 & 22.52 & 25.25 & 28.69 & 24.29 & 24.64 & 24.80 & 25.73 \\
\hline
\end{tabular}

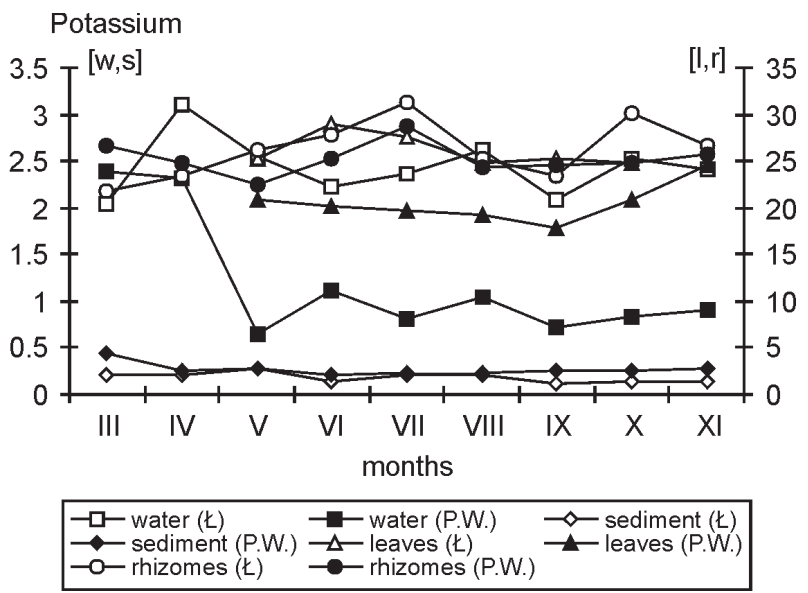

Fig. 5. Variations in $\mathrm{K}$ concentrations during the study period: $\mathrm{w}$ - water $\mathrm{mg} / \mathrm{dm}^{3} ; \mathrm{s}$ - sediment $\mathrm{g} / \mathrm{kg}$ dry matter; 1 - leaves $\mathrm{g} / \mathrm{kg}$ dry matter; $\mathrm{r}$ - rhizomes and roots $\mathrm{g} / \mathrm{kg}$ dry matter; $Ł$ - Lake Łaśmiady; P.W. - Lake Pływające Wyspy.

$\mathrm{K}$ contents were recorded in July. In November the K values were similar.

It may be concluded, therefore, that the $\mathrm{K}$ content of leaves, rhizomes and roots of Nuphar lutea was correlated with the $\mathrm{K}$ content of water and sediments $(\mathrm{R}=0.99$ in all cases).

\section{Sodium}

Sodium stimulates cell growth and has been shown to substitute partially for potassium (Taiz and Zeiger 2006). Nowotny-Mieczyńska (1965) indicated that plants took up relatively large amounts of sodium when potassium was deficient. It is one of the most important macroelements in the waters of eutrophic lakes. During the growing season the variations in sodium concentration are relatively small.

The Na values for oligo-humotrophic lakes are 3-4 times lower than for eutrophic lakes. A similar scenario was observed in the waters of the phytocoenoses N-N from Lake Łaśmiady and Lake Pływające Wyspy (Table 5, Fig. 6).
During the growing season larger variations in $\mathrm{Na}$ concentrations of water were noted in Lake Łaśmiady. In both phytocoenoses there was a slight decrease in Na concentration at the end of the growing season (the decline was bigger in the case of Lake Łaśmiady).

As in the case of water, the variations in $\mathrm{Na}$ content of sediments in Lake Łaśmiady were higher than those for the substrates of Lake Pływające Wyspy. In Lake Pływające Wyspy the Na levels in the sediment declined from March to April. At the height of the growing season the $\mathrm{Na}$ values remained fairly constant. At the end of the growing season the $\mathrm{Na}$ values were more than two times lower than in March. In the case of sediments of Lake Laśmiady the $\mathrm{Na}$ contents increased from March to April and then decreased from May to June, and returned to values attained before the growing season. The highest $\mathrm{Na}$ levels were detected in August. During this period the values of this element were four times higher than those for Lake Pływające Wyspy. In November the $\mathrm{Na}$ contents of sediments from Lake Łaśmiady were similar to those from March.

The pattern of changes in Na content of leaves of Nuphar lutea from Lake Łaśmiady and Lake Pływające Wyspy were striking. In May the levels of this element in the leaves sampled in Lake Łaśmiady were three times higher than in the leaves from Lake Pływające Wyspy. After the Na content of leaves decreased slightly in June (at the peak of the flowering period), it remained at a constant level until August and then declined sharply. The Na levels in the leaves of Nuphar lutea from Lake Pływające Wyspy gradually increased during the entire growing season. At the end of the growing season the $\mathrm{Na}$ values for Lake Pływające Wyspy were 2.5 times higher than those for Lake Łaśmiady.

Different patterns of changes were observed in the $\mathrm{Na}$ content of rhizomes and roots of Nuphar lutea in the Lakes Łaśmiady and Pływające Wyspy from spring to autumn. In both lakes the $\mathrm{Na}$ values at the beginning of the growing season were higher than in November. In Lake Łaśmiady the rhizomes and roots contained greater concentrations of $\mathrm{Na}$ than those from Lake Pływające Wyspy. In August the differences were roughly five-fold. The $\mathrm{Na}$ levels in the 
TABLE 5. Sodium concentrations in water, sediment, leaves, rhizomes and roots

\begin{tabular}{|c|c|c|c|c|c|c|c|c|c|}
\hline Lakes & III & IV & $\mathrm{V}$ & VI & VII & VIII & IX & $\mathrm{X}$ & XI \\
\hline \multicolumn{10}{|c|}{ WATER mg/dm ${ }^{3}$} \\
\hline Łaśmiady & 4.71 & 4.03 & 5.12 & 4.80 & 5.16 & 5.13 & 4.49 & 4.89 & 4.29 \\
\hline Pływające Wyspy & 1.06 & 1.34 & 1.13 & 1.32 & 1.24 & 1.29 & 0.87 & 1.25 & 0.94 \\
\hline \multicolumn{10}{|c|}{ SEDIMENT g/kg dry matter } \\
\hline Łaśmiady & 0.22 & 0.36 & 0.22 & 0.23 & 0.33 & 0.44 & 0.32 & 0.39 & 0.22 \\
\hline Pływające Wyspy & 0.25 & 0.11 & 0.14 & 0.14 & 0.12 & 0.10 & 0.15 & 0.10 & 0.09 \\
\hline \multicolumn{10}{|c|}{ LEAVES g/kg dry matter } \\
\hline Łaśmiady & - & - & 4.65 & 4.26 & 4.88 & 4.96 & 4.14 & 1.72 & - \\
\hline Pływające Wyspy & - & - & 1.43 & 2.34 & 3.04 & 3.31 & 3.53 & 3.75 & 4.59 \\
\hline \multicolumn{10}{|c|}{ RHIZOMES and ROOTS g/kg dry matter } \\
\hline Łaśmiady & 1.70 & 2.82 & 2.94 & 3.25 & 3.52 & 4.47 & 2.78 & 2.99 & 1.11 \\
\hline Pływajace Wyspy & 1.06 & 1.08 & 0.65 & 0.82 & 1.29 & 0.80 & 0.83 & 0.59 & 0.61 \\
\hline
\end{tabular}

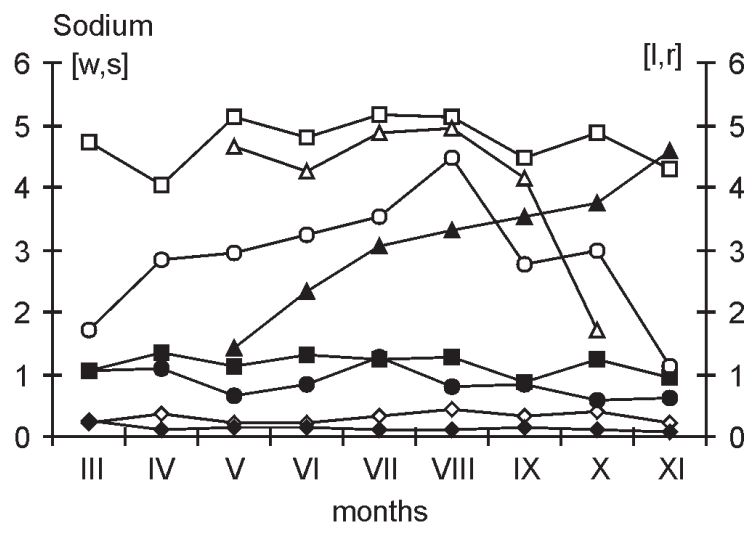

\begin{tabular}{|c|c|c|}
\hline $\begin{array}{l}-\square-\text { water }(t) \\
-\sim \text { sediment }(P . W .)\end{array}$ & $\begin{array}{l}- \text { - water (P.W.) } \\
-\Delta-\text { leaves ( }(\mathrm{L}) \\
- \text { - rhizomes (P.W.) }\end{array}$ & $\begin{array}{l}\smile \text { sediment }(t) \\
\neg-\text { leaves (P.W.) }\end{array}$ \\
\hline
\end{tabular}

Fig. 6. Variations in Na concentrations during the study period: $w$ - water $\mathrm{mg} / \mathrm{dm}^{3}$; $\mathrm{s}$ - sediment $\mathrm{g} / \mathrm{kg}$ dry matter; $\mathrm{l}$ - leaves $\mathrm{g} / \mathrm{kg}$ dry matter; $\mathrm{r}$ - rhizomes and roots $\mathrm{g} / \mathrm{kg}$ dry matter; Ł - Lake Łaśmiady; P.W. - Lake Pływające Wyspy.

rhizomes and roots of Nuphar lutea from Lake Łaśmiady increased from March to August and then declined sharply starting in August. In the case of Lake Pływające Wyspy the Na content decreased to May and then increased until July when the highest level was reached. From July to October the levels of this element gradually declined.

The highest $\mathrm{Na}$ concentrations observed in the leaves, rhizomes and roots of Nuphar lutea from Lake Łaśmiady were related to the highest concentrations of this element in the water and sediments. However, no such a relationship was found in the case of Nuphar lutea from Lake Pływające Wyspy.

Czerwiński and Traczyk (1985) noted that the content of $\mathrm{Na}$ in Nuphar lutea was lower than that of K. This observation agrees with the results obtained in the present study (Tables 4 and 5, Figs 5 and 6).

\section{Calcium}

Plants take up dissolved calcium ions $\mathrm{Ca}^{2+}$ from the soil only in a relatively low-pH environment (Kopcewicz and Lewak 1998). Therefore the total content of Ca in the soil cannot determine the amount of calcium available to plants.

Mengel and Kirkby (1983) demonstrated that plants were able to grow quite well at low $\mathrm{Ca}$ concentrations when other bivalent cations were also in low concentrations. Higher $\mathrm{Ca}$ contents in plants are required for detoxification of bivalent ions.

Significant differences were found with regard to $\mathrm{Ca}$ concentration between the waters of the phytocoenoses investigated. The levels of this element in Lake Łaśmiady were ten times higher than in Lake Pływające Wyspy. The largest differences were noted in March (Table 6, Fig. 7). The Ca levels in the waters of the N-N phytocoenosis from Lake Łaśmiady decreased from spring to autumn (biological decalcification of water) and then increased considerably in November. In the case of the phytocoenosis from Lake Pływające Wyspy the variations in Ca levels were relatively small. A minimum increase in $\mathrm{Ca}$ was noted from May to July. A reverse trend was observed in the case of Lake Łaśmiady, where lower values of Ca were recorded at the end of the growing season than at its beginning.

Bernatowicz (1960) recognized Nuphar lutea as being an indicator species of calcium-poor waters, which was not confirmed in this study. In extreme cases, the species can grow in calcium-poor habitats (e.g. Lake Pływające Wyspy). However such habitat conditions do not appear to be optimal for the species growth.

As in the case of water, the Ca levels in the sediments of the N-N phytocoenosis from Lake Łaśmiady were ten times higher than those in the sediments of Lake Pływające Wyspy. In addition considerable variations in $\mathrm{Ca}$ content were observed in particular months. The highest $\mathrm{Ca}$ values were noted in April as well as in September and October. The sediments of Lake Laśmiady had slightly higher $\mathrm{Ca}$ contents in November than in March. The Ca levels in the sediments of Lake Pływające Wyspy remained constant 
TABLE 6. Calcium concentrations in water, sediment, leaves, rhizomes and roots.

\begin{tabular}{|c|c|c|c|c|c|c|c|c|c|}
\hline${ }^{\text {Month }}$ & III & IV & V & VI & VII & VIII & IX & $X$ & XI \\
\hline \multicolumn{10}{|c|}{ WATER mg/dm ${ }^{3}$} \\
\hline Łaśmiady & 40.65 & 37.15 & 34.73 & 35.30 & 31.85 & 31.58 & 24.85 & 26.60 & 29.03 \\
\hline Pływające Wyspy & 1.67 & 2.50 & 3.56 & 3.42 & 3.42 & 2.73 & 2.59 & 2.84 & 2.86 \\
\hline \multicolumn{10}{|c|}{ SEDIMENT $\mathrm{g} / \mathrm{kg}$ dry matter } \\
\hline Łaśmiady & 24.20 & 39.73 & 24.37 & 27.95 & 36.86 & 33.93 & 38.44 & 46.62 & 30.05 \\
\hline Pływające Wyspy & 2.18 & 2.42 & 2.16 & 3.04 & 2.43 & 2.53 & 2.40 & 1.76 & 1.80 \\
\hline \multicolumn{10}{|c|}{ LEAVES g/kg dry matter } \\
\hline Łaśmiady & - & - & 3.04 & 4.06 & 7.10 & 8.38 & 7.77 & 7.77 & - \\
\hline Pływające Wyspy & - & - & 3.35 & 9.75 & 6.32 & 7.07 & 7.25 & 7.19 & 8.32 \\
\hline \multicolumn{10}{|c|}{ RHIZOMES and ROOTS g/kg dry matter } \\
\hline Łaśmiady & 2.45 & 2.27 & 2.82 & 2.83 & 2.78 & 2.39 & 2.10 & 2.12 & 1.55 \\
\hline Pływające Wyspy & 3.78 & 3.52 & 3.63 & 4.16 & 4.08 & 4.05 & 3.49 & 3.85 & 3.82 \\
\hline
\end{tabular}

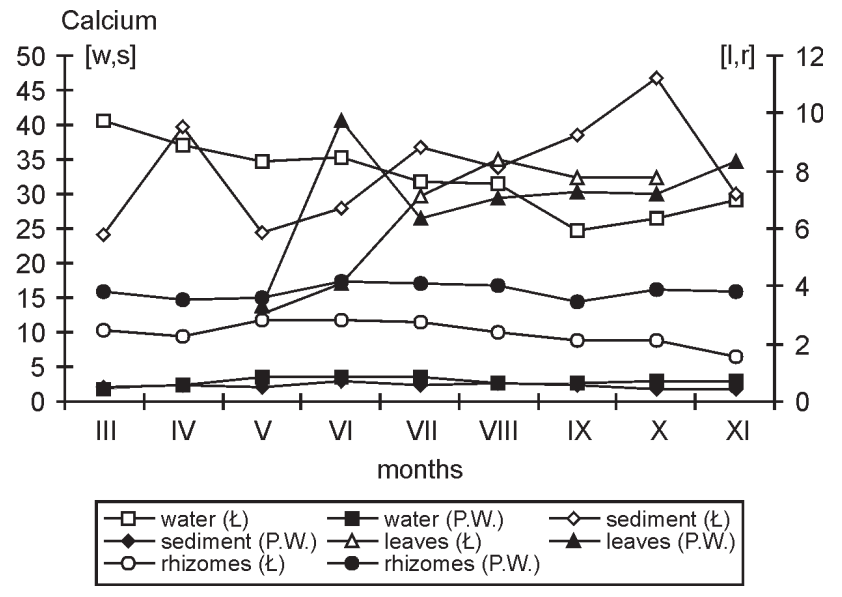

Fig. 7. Variations in Ca concentrations during the study period: $w$ - water $\mathrm{mg} / \mathrm{dm}^{3} ; \mathrm{s}$ - sediment $\mathrm{g} / \mathrm{kg}$ dry matter; 1 - leaves $\mathrm{g} / \mathrm{kg}$ dry matter; $\mathrm{r}$ - rhizomes and roots $\mathrm{g} / \mathrm{kg}$ dry matter; $\mathrm{-} \mathrm{Lake} \mathrm{Laśmiady;} \mathrm{P.W.} \mathrm{-} \mathrm{Lake} \mathrm{Pły-}$ wające Wyspy.

during the entire study period. Slightly lower Ca contents were detected in November than in March.

It is generally recognized that $\mathrm{Ca}$ concentration in the soil solution is ten times higher than that of potassium. The present study showed that this applied only to the sediments of the phytocoenosis from Lake Pływające Wyspy. In the case of sediments from Lake Laśmiady the differences were more than two hundred-fold (Tables 4 and 6, Figs 5 and 7).

The leaves of Nuphar lutea from the two N-N phytocoenoses studied contained similar amounts of $\mathrm{Ca}$. In May, and during the flowering period (in June), the Ca contents of the leaves sampled in Lake Pływające Wyspy were higher than those of the leaves from Lake Łaśmiady. In the following months slightly higher levels of $\mathrm{Ca}$ were detected in the leaves of Nuphar lutea from Lake Laśmiady. In both phytocoenoses the $\mathrm{Ca}$ values at the end of the growing season were more than two times higher than at its begin- ning. The results obtained in this study do not confirm the findings of other authors who indicated that calcium intake into leaves was much lower after the leaves matured even when a stable level of transpiration was maintained. The present findings, however, agree well with the data in literature indicating that calcium does not move down the plant (e.g. towards the rhizomes). Once calcium has been accumulated in old leaves, it cannot be translocated to the young parts of the plant. Therefore a slight increase of $\mathrm{Ca}$ concentration in the waters at the end of the growing season may be associated with the release of this element from the decaying and decomposing leaves.

The Ca content of the rhizomes and roots of Nuphar lutea from the two phytocoenoses studied was negatively correlated with the $\mathrm{Ca}$ content of water and sediments $(\mathrm{R}=$ -0.52 to -0.43$)$. During the entire growing season the roots and rhizomes of Nuphar lutea from Lake Łaśmiady contained lower amounts of $\mathrm{Ca}$ than those from Lake Pływające Wyspy. No appreciable variations in Ca content were found in the two lakes studied during the growing season. In November the Ca levels in the rhizomes and roots of $\mathrm{Nu}$ phar lutea from the acidic oligo-humotrophic Lake Pływajace Wyspy were more than two times higher than those from the alkaline eutrophic Lake Łaśmiady. The present results do not confirm the findings of other authors (Kopcewicz and Lewak 1998) who indicated that during the growing season the contents of $\mathrm{N}, \mathrm{P}$ and $\mathrm{K}$ decreased but $\mathrm{Ca}$ showed an increase with the age of plants. The Ca levels in the leaves were similar to those in the rhizomes and did not change significantly at the end of the growing season.

In conclusion, this study showed that there was not a relationship between the $\mathrm{Ca}$ content of water and sediments and the $\mathrm{Ca}$ content of leaves. The $\mathrm{Ca}$ leaf content was similar in calcium-rich and calcium-poor habitats. A negative correlation was observed in the case of rhizomes and roots. During the entire growing season the Ca levels in the rhizomes and roots of Nuphar lutea from the calcium-poor oligo-humotrophic lake were higher than those from the calcium-rich eutrophic lake. 


\section{Total iron}

Iron uptake is greatly influenced by other cations. Bivalent ions such as $\mathrm{Mn}, \mathrm{Cu}, \mathrm{Ca}, \mathrm{Mg}, \mathrm{Zn}$ and $\mathrm{K}$ compete with iron for absorption. Heavy metals can also affect Fe uptake. The uptake of Fe decreases with increasing $\mathrm{pH}$ and elevated levels of $\mathrm{Ca}$ and $\mathrm{PO}_{4}$. Factors such as high $\mathrm{pH}$ and good soil aeration favour the oxidation of $\mathrm{Fe}^{2+}$ to $\mathrm{Fe}^{3+}$, which leads to precipitation of ferric salts. High calcium concentrations that occur in habitats or in plants can have a negative effect on the physiological activity of iron.

The waters of the two phytocoenoses studied were characterized by similar levels of iron (Table 7, Fig. 8). In spring and autumn the waters of the phytocoenosis in Lake Pływające Wyspy were richer in Fe. During the summer period the Fe levels were higher in the case of the waters of the phytocoenosis in Lake Laśmiady. In both lakes higher values were recorded at the beginning of the growing season than in November. During the growing season the Fe concentrations varied little in the phytocoenoses studied.

The sediments of the phytocoenoses studied contained different amounts of $\mathrm{Fe}$ in various months and the levels of this element varied considerably during the growing season. In the case of the phytocoenosis from Lake Pływające Wyspy the Fe content of sediments showed a decrease from May to July. A rapid increase in Fe was observed from July to October followed by a drastic decline in November. The levels of this element in November were much lower than at beginning of the growing season. The sediments of Lake Łaśmiady contained similar amounts of iron at the beginning and end of the growing season. There were more noticeable differences found between the lowest and highest values of $\mathrm{Fe}$ in the case of Lake Pływajace Wyspy. The Fe content exhibited considerable variations in the particular months. Perhaps much of the iron is not taken up by Nuphar lutea due to the high calcium content in the sediment. Under these conditions iron may be in a form that is inaccessible to plants.

For almost the entire growing season the Fe content of leaves of Nuphar lutea in the phytocoenosis from Lake Pływające Wyspy was slightly higher than that of the lea-

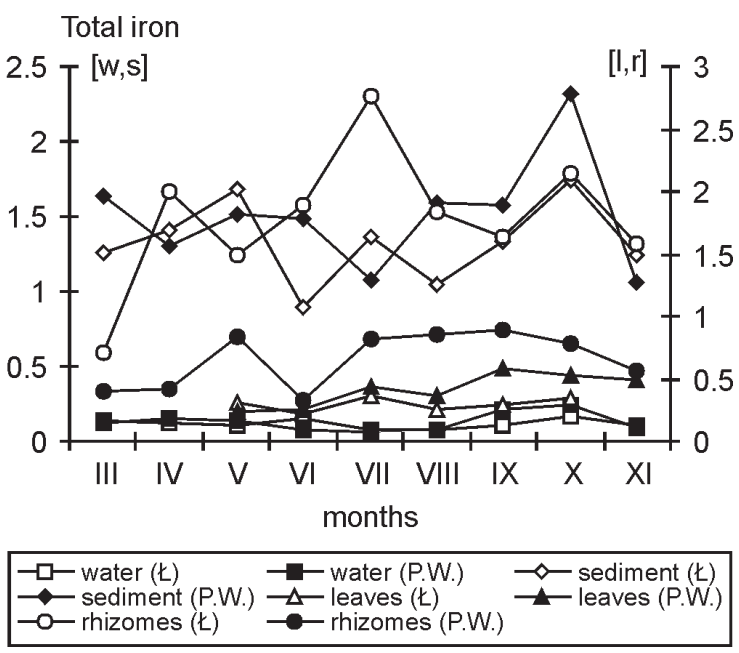

Fig. 8. Variations in total Fe concentrations during the study period: w water $\mathrm{mg} / \mathrm{dm}^{3}$; $\mathrm{s}$ - sediment $\mathrm{g} / \mathrm{kg}$ dry matter; 1 - leaves $\mathrm{g} / \mathrm{kg}$ dry matter; $\mathrm{r}$ - rhizomes and roots $\mathrm{g} / \mathrm{kg}$ dry matter; $\mathrm{Ł}$ - Lake Łaśmiady; P.W. - Lake Pływające Wyspy.

ves sampled in Lake Łaśmiady. In both lakes the Fe content of the leaves from Lake Laśmiady followed a similar dynamic as described for Lake Pływające Wyspy. In the leaves collected from Lake Pływające Wyspy the levels of Fe recorded at the end of the growing season were two times higher than at the beginning of the growing season. In the case of leaves of Nuphar lutea from Lake Łaśmiady these differences were minimal.

A reverse trend was demonstrated in the case of rhizomes and roots sampled in the phytocoenosis in Lake Łaśmiady, which contained higher amounts of $\mathrm{Fe}$ than those from Lake Pływajace Wyspy. In July these differences were three-fold. In both phytocoenoses higher levels of $\mathrm{Fe}$ in Nuphar lutea were detected at the end of the growing season than in March. During the growing season much larger variations of iron levels were noted in the phytocoenosis from Lake Łaśmiady. The results obtained in this study showed that the Fe content of rhizomes and roots probably did not relate to the $\mathrm{Fe}$ content of the water and sediments.

TABLE 7. Total iron concentrations in water, sediment, leaves, rhizomes and roots

\begin{tabular}{|c|c|c|c|c|c|c|c|c|c|}
\hline Lakes & III & IV & V & VI & VII & VIII & IX & $\mathrm{X}$ & XI \\
\hline \multicolumn{10}{|c|}{ WATER mg/dm³ } \\
\hline Łaśmiady & 0.13 & 0.12 & 0.10 & 0.15 & 0.08 & 0.08 & 0.11 & 0.17 & 0.10 \\
\hline Pływające Wyspy & 0.12 & 0.15 & 0.14 & 0.07 & 0.06 & 0.07 & 0.21 & 0.25 & 0.09 \\
\hline
\end{tabular}

SEDIMENT g/kg dry matter

\begin{tabular}{lllllllll}
\hline Laśmiady & 1.26 & 1.41 & 1.68 & 0.89 & 1.36 & 1.05 & 1.33 & 1.75 \\
Pływające Wyspy & 1.64 & 1.31 & 1.51 & 1.48 & 1.08 & 1.59 & 1.57 & 2.32 \\
\hline
\end{tabular}

LEAVES g/kg dry matter

\begin{tabular}{|c|c|c|c|c|c|c|c|c|c|}
\hline Łaśmiady & - & - & 0.31 & 0.22 & 0.37 & 0.26 & 0.30 & 0.34 & - \\
\hline Pływające Wyspy & - & - & 0.23 & 0.26 & 0.43 & 0.37 & 0.58 & 0.52 & 0.50 \\
\hline
\end{tabular}

RHIZOMES and ROOTS g/kg dry matter

\begin{tabular}{lllllllll}
\hline Laśmiady & 0.71 & 2.00 & 1.49 & 1.89 & 2.76 & 1.84 & 1.63 & 2.15 \\
Pływające Wyspy & 0.40 & 0.41 & 0.83 & 0.33 & 0.81 & 0.86 & 0.90 & 0.79 \\
\hline
\end{tabular}


Nowotny-Mieczyńska (1965) noted that iron was accumulated in underground plant parts, which was confirmed by the present findings indicating that the Fe content of rhizomes and roots was higher than that of the leaves.

When lower levels of Fe were noted in the waters and sediments the content of this element in the rhizomes and roots was usually much higher. A reverse trend was determined for the leaves the higher the level of Fe in habitats (water and sediments) - the higher the Fe content in leaves.

\section{Sulphates}

Plants take up sulphur in the form of sulphates. The uptake of sulphur is found to be practically independent of $\mathrm{pH}$. The optimum $\mathrm{pH}$ for sulphur uptake is $\approx 6.5$. In higher plants sulphates are translocated from the roots to the upper plant parts but rarely in the opposite direction. Sulphur does not move readily from older to young leaves.

Before the growing season the $\mathrm{SO}_{4}$ concentrations in the waters of $\mathrm{N}-\mathrm{N}$ phytocoenosis from Lake Łaśmiady were ten times greater than those in Lake Pływające Wyspy (Table 8, Fig. 9). In both cases the $\mathrm{SO}_{4}$ values decreased in April and then increased sharply in May. In the following months, the variations in $\mathrm{SO}_{4}$ levels were similar in the case of the two lakes studied. In November the $\mathrm{SO}_{4}$ concentrations in the waters of both lakes were higher than in April (almost two times higher in Lake Laśmiady and more than four times higher in Lake Pływające Wyspy). At the end of the growing season the concentrations of $\mathrm{SO}_{4}$ were approximately three times as high in the waters of Lake Łaśmiady compared to Lake Pływające Wyspy.

The sediments of the two phytocoenoses studied differed with respect to the $\mathrm{SO}_{4}$ content. However these differences were not so noticeable as in the case of water (except for $\mathrm{SO}_{4}$ in March). Before the growing season $\mathrm{SO}_{4}$ content in the sediments of Lake Pływające Wyspy was ten-fold higher than in the substrates of Lake Łaśmiady. During the first part of the growing season higher $\mathrm{SO}_{4}$ levels were noted in the sediments of Lake Pływające Wyspy, and during the second part of the season - in the sediments of Lake Łaśmiady. The highest $\mathrm{SO}_{4}$ contents in the substrates of

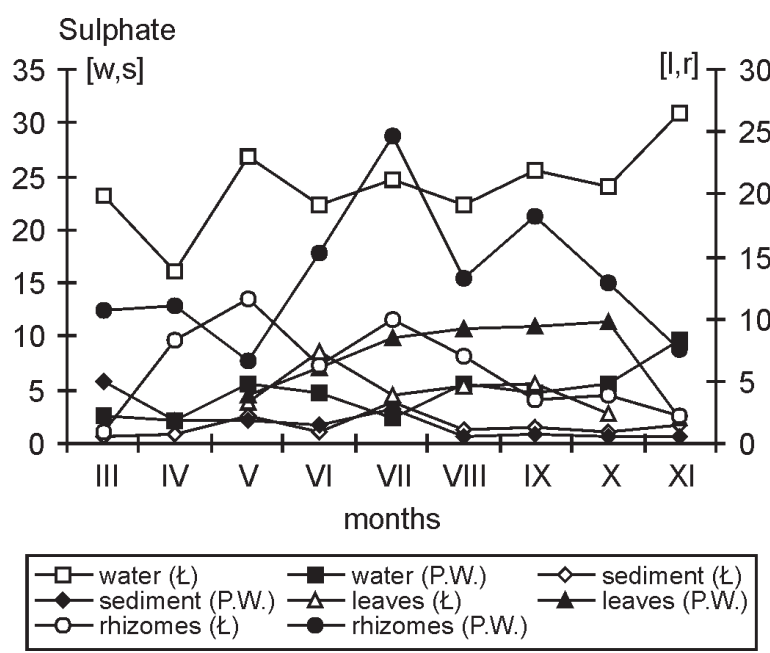

Fig. 9. Variations in $\mathrm{SO}_{4}$ concentrations during the study period: $\mathrm{w}-\mathrm{wa}$ ter $\mathrm{mg} / \mathrm{dm}^{3} ; \mathrm{s}$ - sediment $\mathrm{g} / \mathrm{kg}$ dry matter; 1 - leaves $\mathrm{g} / \mathrm{kg}$ dry matter; $\mathrm{r}$ rhizomes and roots $\mathrm{g} / \mathrm{kg}$ dry matter; $\mathrm{\ell}$ - Lake Łaśmiady; P.W. - Lake Pływające Wyspy.

both lakes were observed in July. At the end of the growing season the sediment of Lake Łaśmiady had higher (two-fold) $\mathrm{SO}_{4}$ contents than in April. A reverse scenario was observed in the case of the sediments from Lake Pływające Wyspy, in which the $\mathrm{SO}_{4}$ levels were more than three times lower than in April, and almost ten times lower than in March.

The $\mathrm{SO}_{4}$ content of leaves collected from the N-N phytocoenosis in Lake Pływające Wyspy was approximately twice or three times as high as that of leaves from Lake Łasmiady during almost the entire growing season. In both phytocoenoses the $\mathrm{SO}_{4}$ levels in the leaves of Nuphar lutea in May were higher than those recorded at the end of the growing season. Although higher values of $\mathrm{SO}_{4}$ were detected in the habitats (water and sediments) of the phytocoenosis from Lake Łaśmiady the leaves of Nuphar lutea from Lake Pływające Wyspy were richer in this nutrient.

The $\mathrm{SO}_{4}$ content of rhizomes and roots was also higher (with the exception of May) in the case of Nuphar lutea

TABLE 8. Sulphate concentrations in water, sediment, leaves, rhizomes and roots.

\begin{tabular}{|c|c|c|c|c|c|c|c|c|c|}
\hline$\times^{\text {Month }}$ & III & IV & V & VI & VII & VIII & IX & $\mathrm{X}$ & XI \\
\hline \multicolumn{10}{|c|}{ WATER mg/dm ${ }^{3}$} \\
\hline Łaśmiady & 23.26 & 16.00 & 26.83 & 22.25 & 24.69 & 22.29 & 25.52 & 24.10 & 30.84 \\
\hline Pływające Wyspy & 2.50 & 2.04 & 5.67 & 4.70 & 2.33 & 5.69 & 4.70 & 5.54 & 9.60 \\
\hline \multicolumn{10}{|c|}{ SEDIMENT g/kg dry matter } \\
\hline Łaśmiady & 0.55 & 0.76 & 2.57 & 1.13 & 3.76 & 1.26 & 1.43 & 1.05 & 1.62 \\
\hline Pływające Wyspy & 5.78 & 2.08 & 2.14 & 1.74 & 3.17 & 0.66 & 0.87 & 0.57 & 0.65 \\
\hline \multicolumn{10}{|c|}{ LEAVES g/kg dry matter } \\
\hline Łaśmiady & - & - & 3.29 & 7.39 & 3.91 & 4.61 & 4.77 & 2.39 & - \\
\hline Pływające Wyspy & - & - & 3.85 & 6.06 & 8.48 & 9.25 & 9.34 & 9.72 & 2.02 \\
\hline
\end{tabular}

RHIZOMES and ROOTS g/kg dry matter

\begin{tabular}{lccccccccc}
\hline Laśmiady & 0.98 & 8.26 & 11.54 & 6.34 & 9.90 & 6.98 & 3.49 & 3.83 & 2.22 \\
Pływające Wyspy & 10.69 & 10.97 & 6.59 & 15.20 & 24.64 & 13.23 & 18.15 & 12.91 & 7.46 \\
\hline
\end{tabular}


from Lake Pływające Wyspy. In March the rhizomes and roots sampled in Lake Pływające Wyspy had ten times as much $\mathrm{SO}_{4}$ as those collected from Lake Łaśmiady. These differences were only three-fold at the end of the growing season. Larger variations in $\mathrm{SO}_{4}$ contents were noted in the rhizomes and roots of the plants from Lake Pływające Wyspy.

It may be concluded from this study that the $\mathrm{SO}_{4}$ content of leaves, rhizomes and roots was negatively correlated with the $\mathrm{SO}_{4}$ content of water and sediments $(\mathrm{R}=-0.66$ to -0.56$)$.

It is generally recognized that plants contain ten times less sulphur than nitrogen. The results obtained in this study indicated that the leaves of Nuphar lutea had three to five times less $\mathrm{SO}_{4}$ than nitrogen (nitrate nitrogen and total nitrogen). The $\mathrm{SO}_{4}$ content of rhizomes and roots sampled in the eutrophic Lake Łaśmiady was two times lower than that of nitrogen, whereas in the oligo-humotrophic Lake Pływające Wyspy the $\mathrm{SO}_{4}$ values were about 1.5 times higher than the $\mathrm{N}$ values. This may be ascribed to higher $\mathrm{SO}_{4}$ levels in the sediments of the latter lake.

\section{Silica dissolved}

After oxygen, silicon is the second most abundant and widespread element in the environment. In a soil solution with $\mathrm{pH}$ below 9 it is found in the form of silicic acid, an undissociated molecule. At $\mathrm{pH}$ above 9 silicon is in the form of silicon ions. Plants contain silicon in the form of silica gel, an amorphous colloidal form of dioxide silica or particles of polymerized silicic acid (Mengel and Kirkby 1983). In silicophilous plants the Si content usually reaches $100 \mathrm{mg} / \mathrm{g}$.

During the entire growing season the variations in $\mathrm{SiO}_{2}$ concentrations in the waters of the Lake Pływające Wyspy were not considerable. The $\mathrm{SiO}_{2}$ levels at the beginning of the growing season were similar to those detected in November (Table 9, Fig. 10). In the case of Lake Łaśmiady the $\mathrm{SiO}_{2}$ concentrations were higher and increased from March to April and then declined. The lowest levels of $\mathrm{SiO}_{2}$ were noted in June and July (at the height of the growing season). Subsequently a sharp increase in the concen-

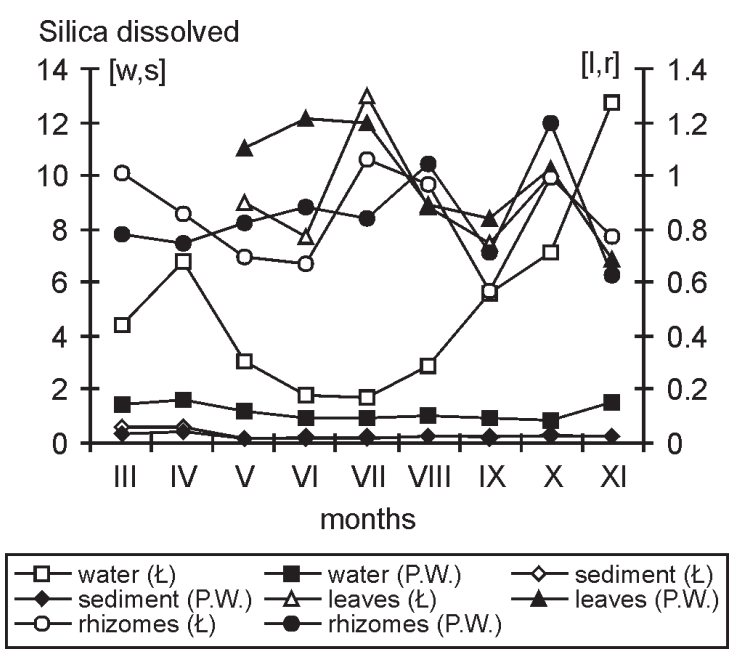

Fig. 10. Variations in $\mathrm{SiO}_{2}$ dissolved concentrations during the study period: $\mathrm{w}$ - water $\mathrm{mg} / \mathrm{dm}^{3} ; \mathrm{s}$ - sediment $\mathrm{g} / \mathrm{kg}$ dry matter; 1 - leaves $\mathrm{g} / \mathrm{kg}$ dry matter; $\mathrm{r}$ - rhizomes and roots $\mathrm{g} / \mathrm{kg}$ dry matter; - Lake Łaśmiady; P.W. - Lake Pływające Wyspy.

tration of $\mathrm{SiO}_{2}$ occurred in August. At the end of the growing season the $\mathrm{SiO}_{2}$ values were two times higher than those obtained from April. In October and November the $\mathrm{SiO}_{2}$ levels in the waters of Lake Łaśmiady were eight times higher than those in Lake Pływające Wyspy.

At the beginning of the growing season, the sediments of the N-N phytocoenosis from Lake Łaśmiady had higher $\mathrm{SiO}_{2}$ content than those from Lake Pływające Wyspy. From May to November there were practically no differences in $\mathrm{SiO}_{2}$ content between the sediments of the two phytocoenoses studied. In November the $\mathrm{SiO}_{2}$ levels in the sediments of both phytocoenoses were two times lower than in March and April.

Although the $\mathrm{SiO}_{2}$ levels were much higher in the habitat of N-N phytocoenosis from Lake Laśmiady than in Lake Pływające Wyspy, the content of this element in the leaves of Nuphar lutea was lower in the case of the former lake. In both lakes similar variations occurred in $\mathrm{SiO}_{2}$ content of leaves during the growing season. In addition the $\mathrm{SiO}_{2}$ va-

TABLE 9. Silica dissolved concentrations in water, sediment, leaves, rhizomes and roots

\begin{tabular}{|c|c|c|c|c|c|c|c|c|c|}
\hline$\times$ & III & IV & V & VI & VII & VIII & IX & $\mathrm{X}$ & XI \\
\hline \multicolumn{10}{|c|}{ WATER mg/dm 3} \\
\hline Łaśmiady & 4.38 & 6.82 & 3.07 & 1.82 & 1.67 & 2.88 & 5.56 & 7.12 & 12.70 \\
\hline Pływające Wyspy & 1.44 & 1.59 & 1.18 & 0.93 & 0.91 & 1.06 & 0.91 & 0.88 & 1.53 \\
\hline
\end{tabular}

SEDIMENT $\mathrm{g} / \mathrm{kg}$ dry matter

\begin{tabular}{llllllllll}
\hline Laśmiady & 0.56 & 0.57 & 0.14 & 0.14 & 0.20 & 0.23 & 0.28 & 0.28 & 0.27 \\
Pływające Wyspy & 0.38 & 0.40 & 0.14 & 0.29 & 0.22 & 0.22 & 0.21 & 0.32 & 0.22 \\
\hline
\end{tabular}

LEAVES g/kg dry matter

\begin{tabular}{llllllllr}
\hline Łaśmiady & - & - & 0.90 & 0.77 & 1.30 & 0.88 & 0.75 & 1.00 \\
Pływające Wyspy & - & - & 1.10 & 1.21 & 1.20 & 0.89 & 0.84 & 1.03 \\
\end{tabular}

RHIZOMES and ROOTS $\mathrm{g} / \mathrm{kg}$ dry matter

\begin{tabular}{llllllllll}
\hline Laśmiady & 1.01 & 0.86 & 0.70 & 0.67 & 1.06 & 0.97 & 0.57 & 0.99 & 0.77 \\
Pływające Wyspy & 0.78 & 0.75 & 0.82 & 0.88 & 0.84 & 1.04 & 0.71 & 1.20 & 0.63 \\
\hline
\end{tabular}


lues recorded in May were comparable to those obtained at the end of the growing season.

The $\mathrm{SiO}_{2}$ content of rhizomes and roots of Nuphar lutea was not related to the $\mathrm{SiO}_{2}$ content of water and sediments. In both phytocoenoses the rhizomes and roots of Nuphar lutea had similar amounts of $\mathrm{SiO}_{2}$. However they exhibited different $\mathrm{SiO}_{2}$ variation patterns during the growing season. In both cases the $\mathrm{SiO}_{2}$ levels in November were slightly lower than in April

\section{Manganese, Cadmium, Zinc, Lead}

Only the samples of leaves, rhizomes and roots collected in July were analysed for $\mathrm{Mn}, \mathrm{Cd}, \mathrm{Zn}$ and $\mathrm{Pb}$ content (due to a shortage of funds). In July, at the height of the growing season, about $50 \%$ of the flowers of Nuphar lutea are in full bloom and the remaining flowers have already withered and set fruit. The data presented in the work were computed as an average from the whole study period (1997-2000). The results obtained showed that the leaves of $\mathrm{Nu}$ phar lutea from Lake Łaśmiady had only higher Cd content than the leaves sampled in Lake Pływające Wyspy. A similar scenario was observed in the case of $\mathrm{Mn}$ and $\mathrm{Pb}$ accumulated in the rhizomes and roots of Nuphar lutea. However, in general, the content of studied microelements is higher in Nuphar lutea in the lake Pływające Wyspy (Table 10, Figs 11a and b). These results are quite difficult to interpret when one considers the location of the phytocoenoses within the lake. In Lake Łaśmiady the phytocoenosis of $\mathrm{N}-\mathrm{N}$ occurs near the edge of the lake in the village of Sajzy. About 5-6 meters from the phytocoenosis there is an asphalt road that leads through the village. Lake Pływające Wyspy is relatively small and has no direct inflow or outflow. It is located within a big forest complex and is completely surrounded by a 50 meter belt peat bog. An infrequently used forest road is situated about $100 \mathrm{~m}$ from the lake.

\section{SUMMARY}

Nuphar lutea occurring in the Nupharo-Nymphaeetum albae phytocoenoses in two very different habitats (eutrophic Lake Łaśmiady and oligo-humotrophic Lake Pływające Wyspy) shows differences between the concentration of the studied components in the leaves and rhizomes with roots. These differences are also found in the case of water and sediments. This is proved by the PCA analysis (Fig. 12), in which parameters occurring in Nuphar lutea and parameters occurring in the environment were divided into

TABLE 10. The contents of $\mathrm{Mn}, \mathrm{Cd}, \mathrm{Zn}$ and $\mathrm{Pb}$ in the leaves, rhizomes and roots.

\begin{tabular}{lllll}
\hline Makes & $\mathrm{Mn}$ & $\mathrm{Cd}$ & $\mathrm{Zn}$ & $\mathrm{Pb}$ \\
\hline \multicolumn{5}{c}{ LEAVES mg/kg dry matter } \\
\hline Eaśmiady & 112.94 & 0.36 & 25.75 & 0.60 \\
PływająceWyspy & 117.00 & 0.28 & 37.72 & 1.99 \\
\hline
\end{tabular}

RHIZOMES and ROOTS mg/kg dry matter

\begin{tabular}{lllll}
\hline Laśmiady & 78.95 & 0.34 & 16.43 & 0.98 \\
PływająceWyspy & 68.09 & 0.42 & 39.47 & 0.33 \\
\hline
\end{tabular}
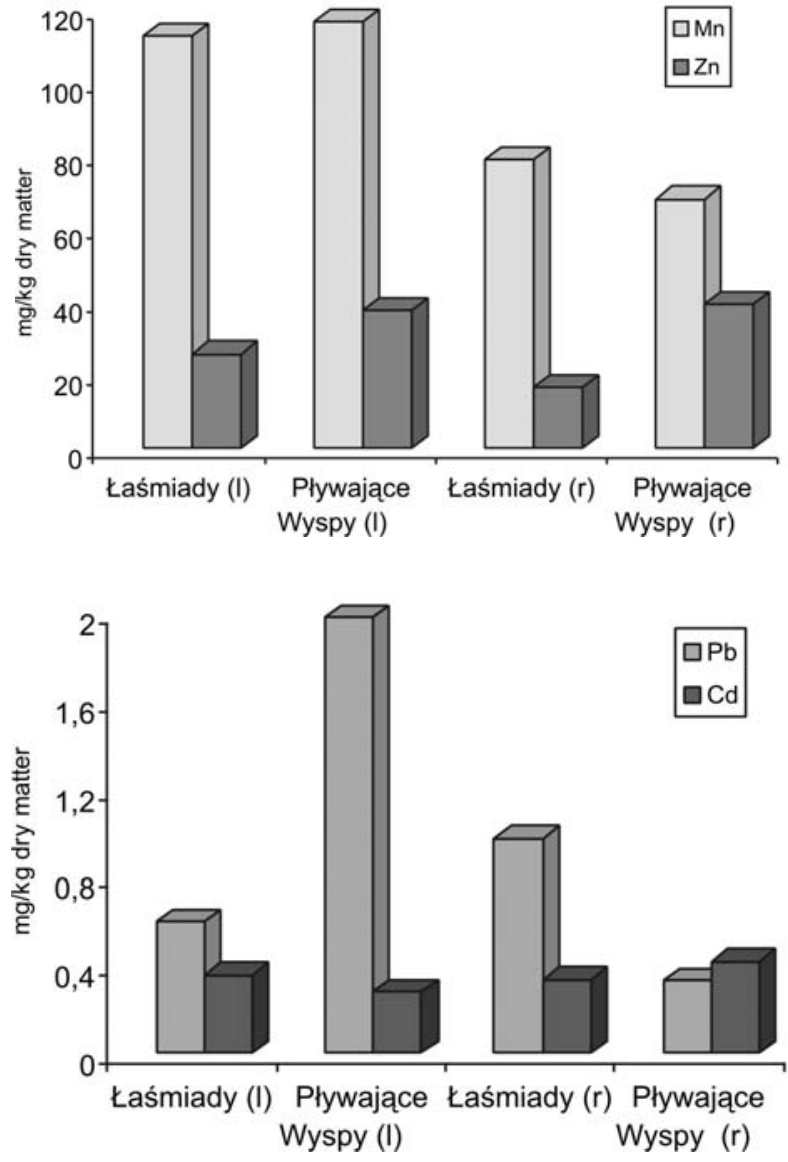

Figs $11 \mathrm{a}$ and $11 \mathrm{~b}$. The contents of the studied microelements in the leaves (l), rhizomes and roots (r).

two independent groups, except for the parameters of water in Lake Łaśmiady. The main reason for taking these two groups under consideration were higher average values of all the studied chemical parameters in Nuphar lutea than in the environment during the whole time of research (Fig. 13). Only the values of parameters in the water of Lake Laśmiady were as high as in Nuphar lutea (Kruskal-Wallis test).

In Lake Łaśmiady the levels of all the water parameters studied (with the exception of iron) were higher than in Lake Pływające Wyspy. The sediments of Lake Łaśmiady were richer in $\mathrm{PO}_{4}, \mathrm{Na}$ and $\mathrm{Ca}$, whereas those of Lake Pływające Wyspy showed higher levels of $\mathrm{NO}_{3}$, total $\mathrm{N}, \mathrm{K}$ and $\mathrm{SO}_{4}$. The total $\mathrm{Fe}$ and $\mathrm{SiO}_{2}$ dissolved concentrations were similar in the two lakes studied.

At the beginning of the growing season the leaves of $\mathrm{Nu}$ phar lutea from both lakes contained higher amounts of $\mathrm{PO}_{4}, \mathrm{NO}_{3}$, total $\mathrm{N}$ and $\mathrm{SO}_{4}$ than at the end of the growing season.

In Lake Pływające Wyspy higher $\mathrm{SiO}_{2}$ dissolved contents were noted at the beginning of the growing season than at its end. A reverse trend was observed in the case of Lake Laśmiady. At the beginning of the growing season the leaves of Nuphar lutea collected from Lake Łaśmiady contained higher concentrations of $\mathrm{K}$ and $\mathrm{Na}$, whereas higher $\mathrm{Ca}$ and total Fe levels were detected in both lakes at the end of the growing season. During the whole study period the leaves of Nuphar lutea from the two phytocoenoses studied showed similar levels of $\mathrm{Ca}$, total $\mathrm{Fe}$ and $\mathrm{SiO}_{2}$ dissolved. Higher contents of $\mathrm{PO}_{4}$, total $\mathrm{N}, \mathrm{K}$ and $\mathrm{Na}$ were 


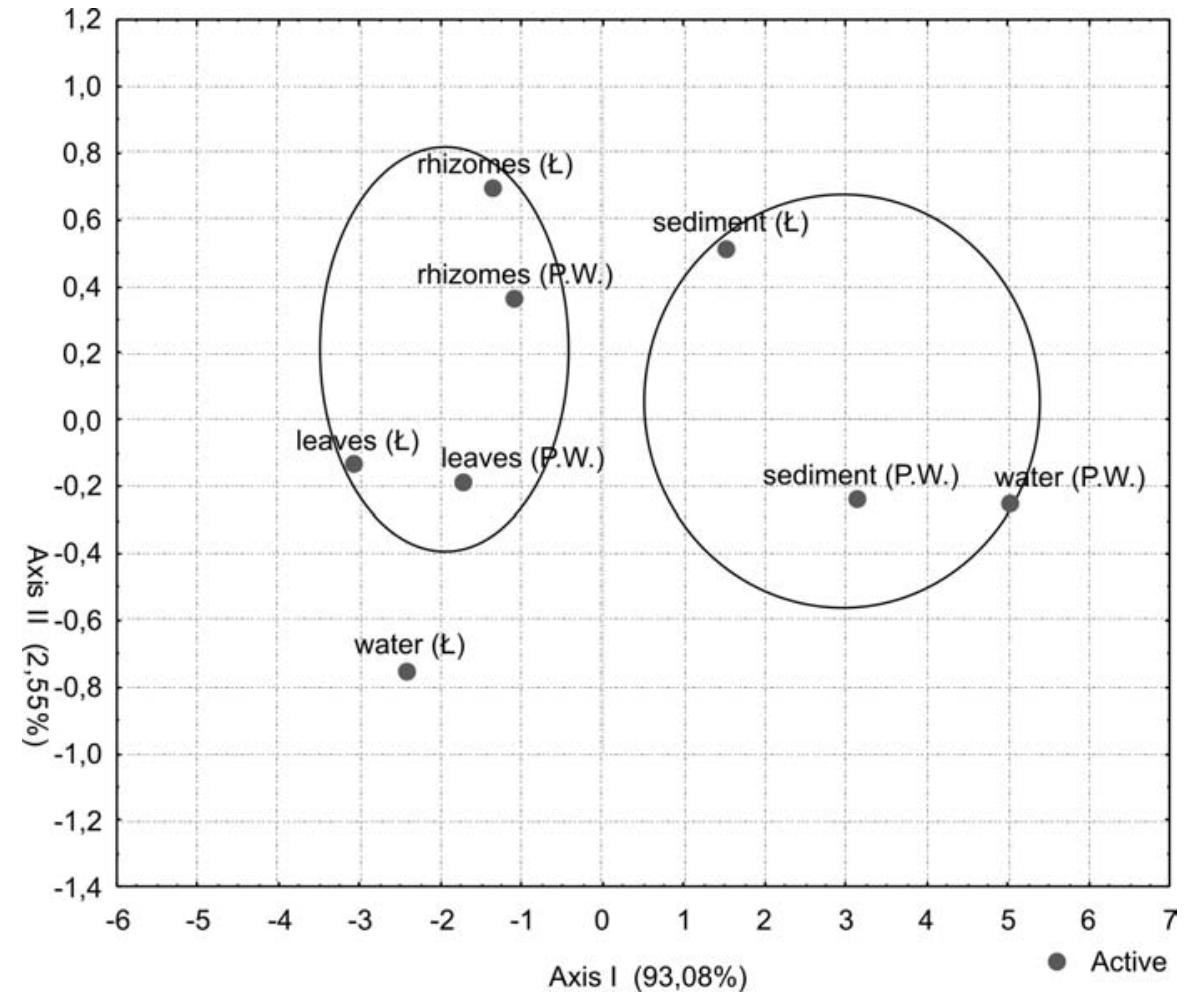

Fig. 12. Principal Components Analysis. Classification of the averages of chemical parameters in Nuphar lutea - (A) and environment of Lakes Łaśmiady ( $\mathrm{E}$ ) and Pływające Wyspy (P.W.) - (B). Two principal components contain $95.63 \%$ of the range of the studied parameters. detected in the leaves of Nuphar lutea collected from Lake Łaśmiady, whereas the leaves from Lake Pływające Wyspy had higher amounts of $\mathrm{NO}_{3}$ and $\mathrm{SO}_{4}$.

In both lakes the $\mathrm{NO}_{3}, \mathrm{Na}$ and $\mathrm{SiO}_{2}$ dissolved contents of rhizomes of Nuphar lutea were higher in before the gro-

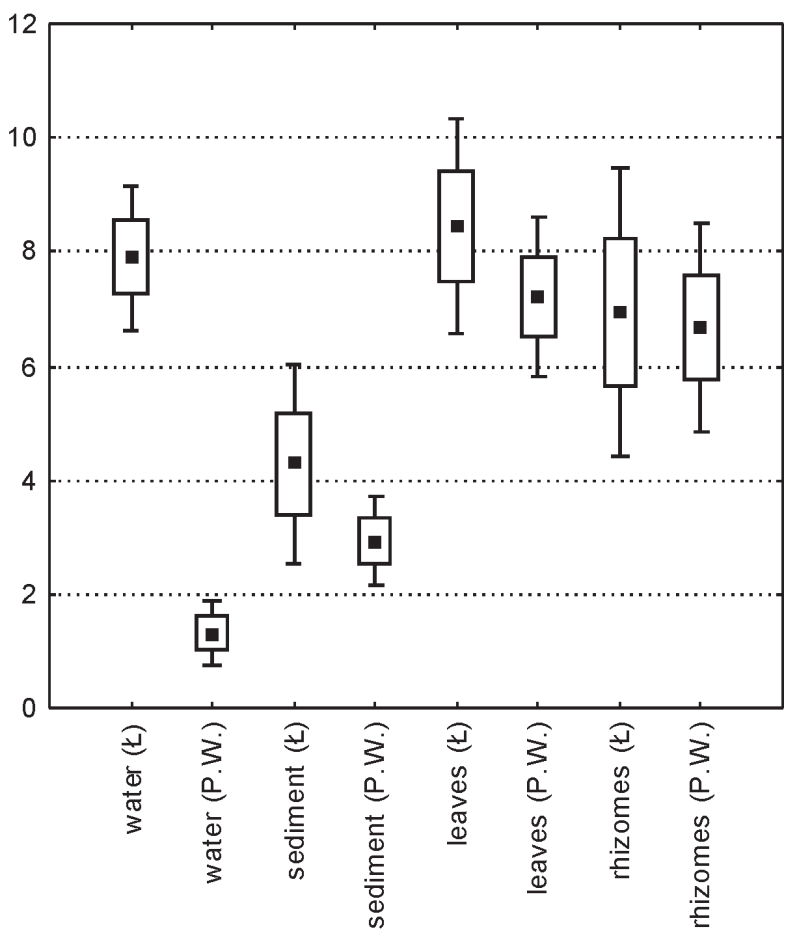

- Average

$\square$ Average \pm Stand.deviation

I Average $\pm 1,96 *$ Stand.deviation

Fig. 13. The values of the studied chemical parameters measured in $\mathrm{Nu}$ phar lutea and in Lakes Łaśmiady (Ł) and Pływające Wyspy (P.W.). wing season than in November, whereas the levels of $\mathrm{PO}_{4}$, total $\mathrm{N}$ and total Fe were higher in November. In Lake Łaśmiady the rhizomes of Nuphar lutea contained higher amounts of $\mathrm{Ca}$ in March than at the end of the growing season, whereas in the case of Lake Pływajace Wyspy higher levels of $\mathrm{K}$ and $\mathrm{SO}_{4}$ were detected. Similar levels of $\mathrm{NO}_{3}$, $\mathrm{K}$ and $\mathrm{SiO}_{2}$ dissolved were noted in the rhizomes and roots of Nuphar lutea during the whole study period. Significantly higher $\mathrm{PO}_{4}$, total $\mathrm{N}, \mathrm{Na}$ and total $\mathrm{Fe}$ values were recorded in the case of Lake Laśmiady during the entire study period, whereas $\mathrm{Ca}$ and $\mathrm{SO}_{4}$ levels were greater in Lake Pływające Wyspy.

The concentrations of the analysed microelements (Mn, $\mathrm{Cd}, \mathrm{Zn}$ and $\mathrm{Pb}$ ) in total, were higher in the case of the oligo-humotrophic Lake Pływające Wyspy.

It was found that the differences in the chemical composition of water and sediment between the two lakes of different trophic types were more pronounced than in the case of leaves, rhizomes and roots of Nuphar lutea (in many cases the plants had similar component levels and their variations).

\section{LITERATURE CITED}

BAYLY I.L., FREEMAN E.A. 1977. Seasonal variation of selected cations in Acorus calamus L. Aquatic Bot., 3: 65-84.

BERNATOWICZ A. 1960. Charakterystyka jezior na podstawie roślin naczyniowych. Rocz. Nauk Roln., Olsztyn, 77b (1): 79-99. (in Polish with Russian summary)

BRAUN-BLANQUET J. 1951. Pflanzensoziologie. Springer Verlang. Wien.

CZERWIŃSKI Z., TRACZYK T. 1985. Chemical composition and acumulation of mineral compounds in plants of Lake Jorzec. Pol. Ecol. Stud. 11 (3-4): 405-421.

GOPAL B., SHARMA K.P. 1984. Seasonal changes in concentration of major nutrient elements in the rhizomes and leaves of Typha elephantina Roxb. Aquatic Bot., 20: 65-73. 
HERMANOWICZ W., DOŻAŃSKA W., DOJLIDO J., KOZIEROWSKI B. 1976. Fizyczno-chemiczne badania wody i ścieków. Arkady, Warszawa. (in Polish)

JONGMAN R.H.G., TER BRAAK C.J.F., van TONGEREN D.F.R. (eds) 1987. Data analisis in community and landscape ecology, Pudoc, Wageningen.

KAJAK Z. 1979. Eutrofizacja jezior. PWN, Warszawa. (in Polish)

KIMBALL K.D., BAKER A.L. 1982. Variations in the mineral content of Myriophyllum heterophyllum Michx related to site and season. Aquatic Bot., 14: 139-149.

KLINK A. 2004. Content of selected chemicals in two protected macrophytes: Nymphaea alba L. and Nuphar lutea (L.) Sibith. \& Sm. in relation to site chemistry. Pol. J. Ecol. 52 (2): 229-232.

KLINK A. 2005a. Chemical changes and nutrient release during decomposition processes of mature leaves of Nuphar lutea (L.) Sibith. \& Sm. under laboratory conditions. Ecohydrology \& Hydrobiology 5 (3): 215-222.

KLINK A. 2005b. Production and elemental composition of floating leaves of Nymphaea alba L. and Nuphar lutea (L.) Sibith. \& Sm. in selected lakes in West Poland. Ecohydrology \& Hydrobiology 5 (3): 223-229.

KLINK A., KRAWCZYK J., LETACHOWICZ B. 2004. Iron and manganese in leaves of Nymphaea alba L. and Nuphar lutea (L.) Sibith. \& Sm. from Pojezierze Leszczyńskie. Roczn. PZH 55 supl.: $177-183$.

KOPCEWICZ J., LEWAK S. 1998. Podstawy fizjologii roślin. PWN, Warszawa. (in Polish)

MARCZONEK A. 1984. Ekologia populacji Conocephallum conicum (L.) Dum. i Pellia epiphylla (L.) Lindb. Acta Uniw. Wratisl. Prace Botaniczne 27: 121-152. (in Polish with English summary)
MENGEL K., KIRKBY E.A. 1983. Podstawy żywienia roślin. PWRiL, Warszawa. (in Polish)

NOWOTNY-MIECZYŃSKA A. 1965. Fizjologia mineralnego żywienia roślin. PWRiL, Warszawa. (in Polish)

OSTROWSKA A., GAWLIŃSKI S., SZCZUBIAŁKA Z. 1991. Metody analizy i oceny właściwości gleb i roślin. Katalog, Inst. Ochrony Środowiska, Warszawa. (in Polish)

OŚWIT J. 1991. Roślinność i siedliska zabagnionych dolin rzecznych na tle warunków wodnych. Rocz. Nauk Roln. ser. D, tom. 221. PWN, Warszawa. (in Polish with English summary)

OŚWIT J., SAPEK B. 1976. Wpływ warunków siedliskowych na zawartość mikroelementów w roślinności łąkowej. Zesz. Probl. Post. Nauk Roln. 176. (in Polish)

OŚWIT J., SAPEK B. 1982. Ocena zawartości składników mineralnych w roślinach łąk naturalnych i zdolność gatunków do wykorzystania zasobów glebowych. Roczn. Gleboznaw. 33 (1-2): 146-151. (in Polish)

SAMECKA-CYMERMAN A. 1995. Mineralne składniki pokarmowe w roślinach wodnych z rzeki Strzegomki i Dobrej. In: SAROSIEK J. Studia nad ekologią roślin wodnych. Prace Botaniczne 67: 57-80. Wyd. Uniw. Wrocławskiego. (in Polish with English summary)

STANISZ A. 1998. Przystępny kurs statystyki. StatSoft Polska Sp. z o.o., Kraków. (in Polish)

STATSOFT INC. 2003. STATISTICA (data analisys software system), version 6. www. Startsoft. Com.

TAIZ L., ZEIGER E. 2006. Plant physiology. Massachusetts.

TER BRAAK C.J.F., ŠMILAUER P. 2002. CANOCO Reference manual and user's guide to Canoco for Windows: Software for Canonical Community Ordination (version 4.5) Microcomputer Power (Itaca, NY, USA). 